\title{
RENAMING PRACTICES: AN AUTOETHNOGRAPHY OF SOUTH ASIAN NAMES, IDENTITY, AND BELONGING \\ by
}

Mandeep Kaur Mann, BA, Sheridan College, 2018

\author{
An MRP \\ presented to Ryerson University \\ in partial fulfillment of the \\ requirements for the degree of \\ Master of Arts \\ in the program of \\ Early Childhood Studies
}

Toronto, Ontario, Canada, 2020

(C) Mandeep Kaur Mann, 2020 


\section{AUTHOR'S DECLARATION}

I hereby declare that I am the sole author of this MRP. This is a true copy of the MRP, including any required final revisions.

I authorize Ryerson University to lend this MRP to other institutions or individuals for the purpose of scholarly research

I further authorize Ryerson University to reproduce this MRP by photocopying or by other means, in total or in part, at the request of other institutions or individuals for the purpose of scholarly research.

I understand that my MRP may be made electronically available to the public. 


\begin{abstract} Master of Arts, 2020

Mandeep Kaur Mann

Early Childhood Studies, Ryerson University
\end{abstract}

Renaming Practices: An Autoethnography of South Asian Names, Identity, and Belonging

Names have been linked to various aspects of identity including ethnicity and language, and family. Studies have shown that the proper use of children's names can reinforce and validate their identity. Research on renaming throughout Canadian history shows how these practices have the ability to dismantle and remove or alter identity. South Asians represent a large portion of Ontario's population. However when their names do not conform to the dominant western culture, South Asians can be marginalized through racist microaggressions that contribute to their renaming. This paper is guided by critical race theory and Desi critical theory and explores the significance of my use of different names and why I chose and continue to choose these names. Using an autoethnographic approach I reflect on my name alteration experiences from my childhood and youth to explore how renaming practices can and do further marginalize minority children.

Keywords: renaming practices; naming; South Asian; identity; belonging; childhood; autoethnography 


\section{ACKNOWLEDGEMENTS}

I would like to thank Dr. Susan Jagger for her endless support throughout this writing process. Thank you for encouraging me to take risks and challenge my thoughts on academic writing. Your belief in me and my work gave me the confidence to centre my voice and create something I am truly proud of.

Thank you to my parents for always believing in me and supporting me through all my endeavors. Thank you to my siblings for always making sure I stayed on track and for providing me with much needed comic relief. A special thank you to my late dog Rocky whose unconditional love and companionship kept me sane throughout this process. I miss you so very much.

I would also like to thank my friends, the Litty Committee, for always keeping me company as I worked. Thank you for staying up with me all hours of the night and for being my sounding board.

Thank you to my cohort for providing me so much support throughout this program. Especially to those who encouraged me and gave me the confidence to pursue this study. This paper could not have existed without you. 


\section{DEDICATION}

This work is dedicated to all those who have been victims of renaming, in hopes that they may one day find the confidence to use their names without fear of judgement. 


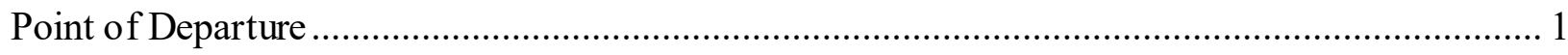

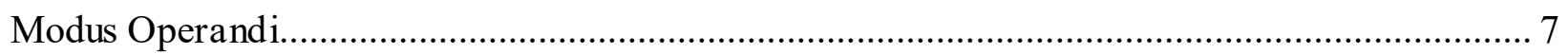

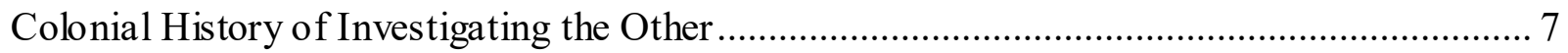

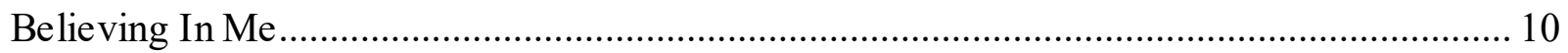

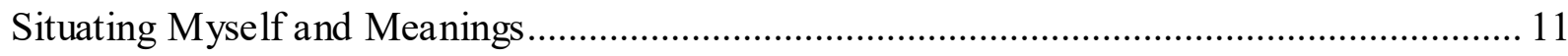

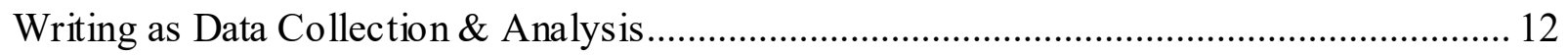

The Ethics of Non-Active Participation............................................................................ 14

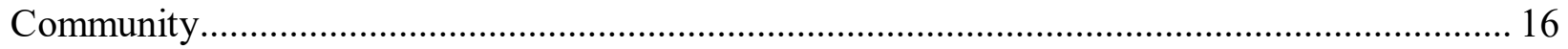

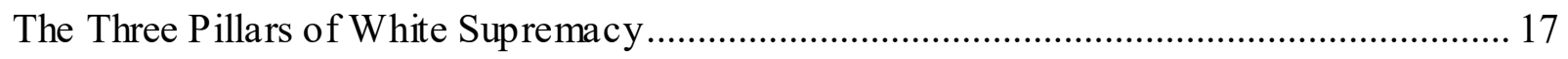

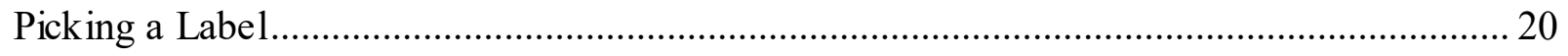

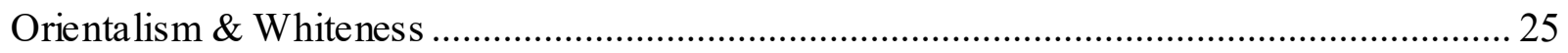

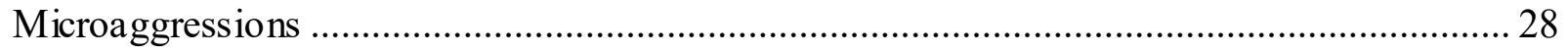

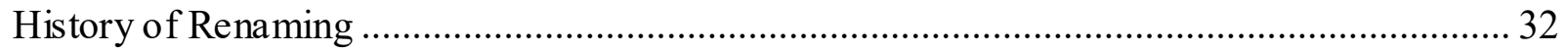

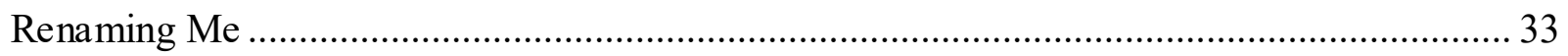

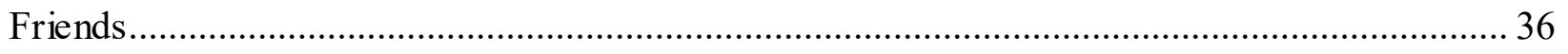

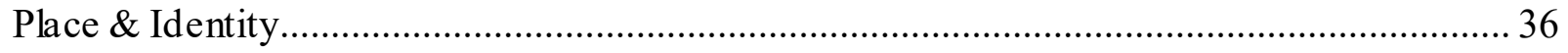

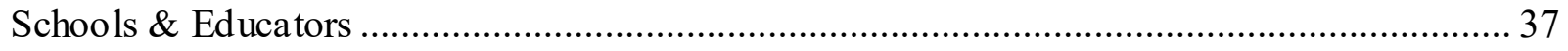

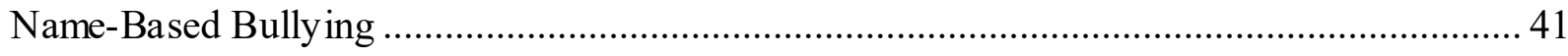




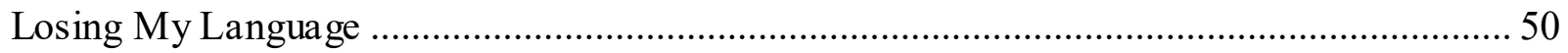

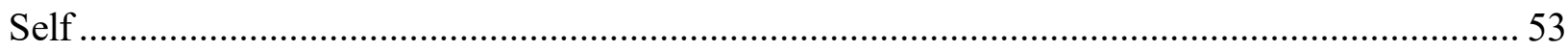

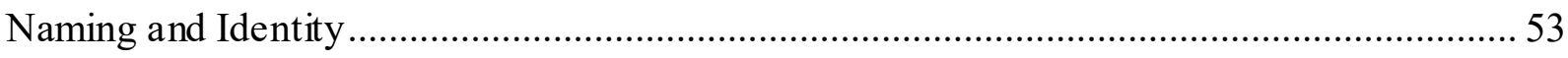

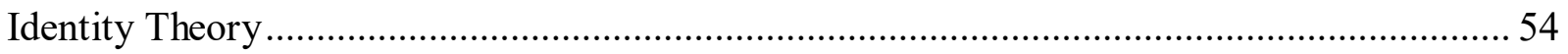

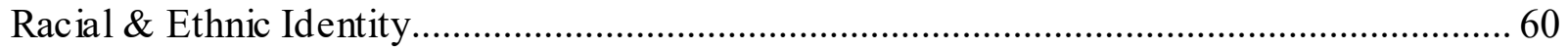

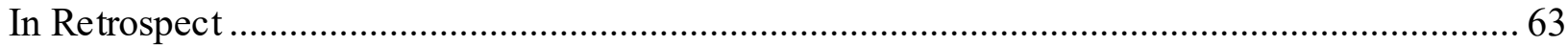

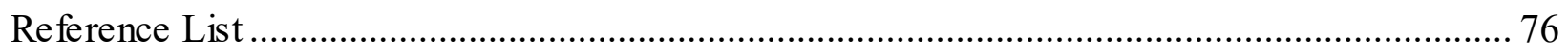




\section{LIST OF ILLUSTRATIONS}

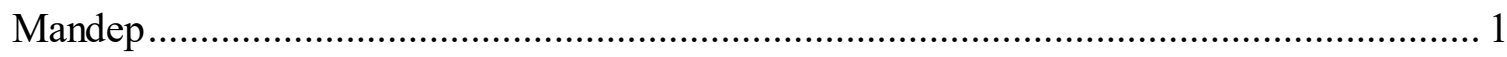

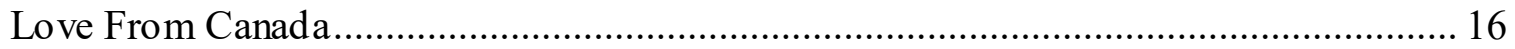

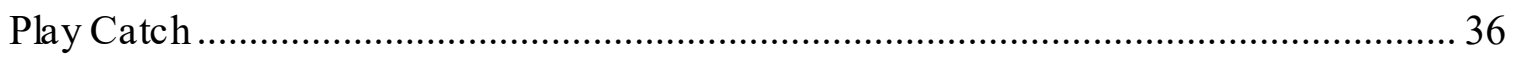

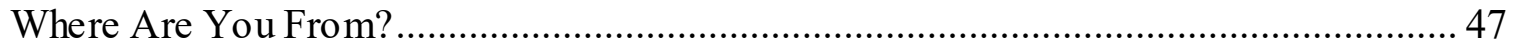

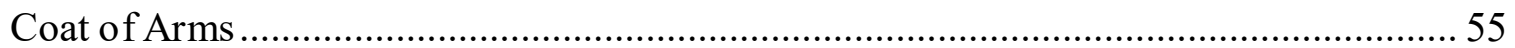




\section{LIST OF APPENDICES}

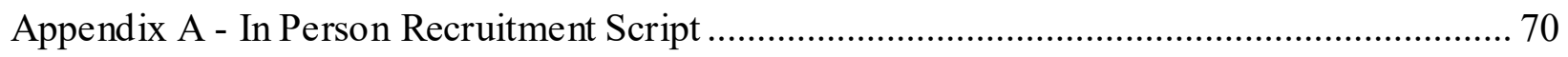

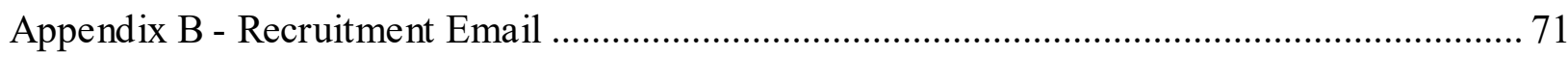

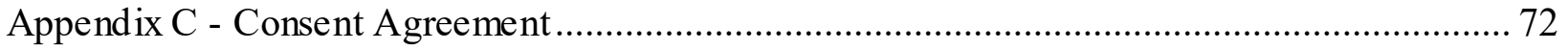




\section{Point of Departure}

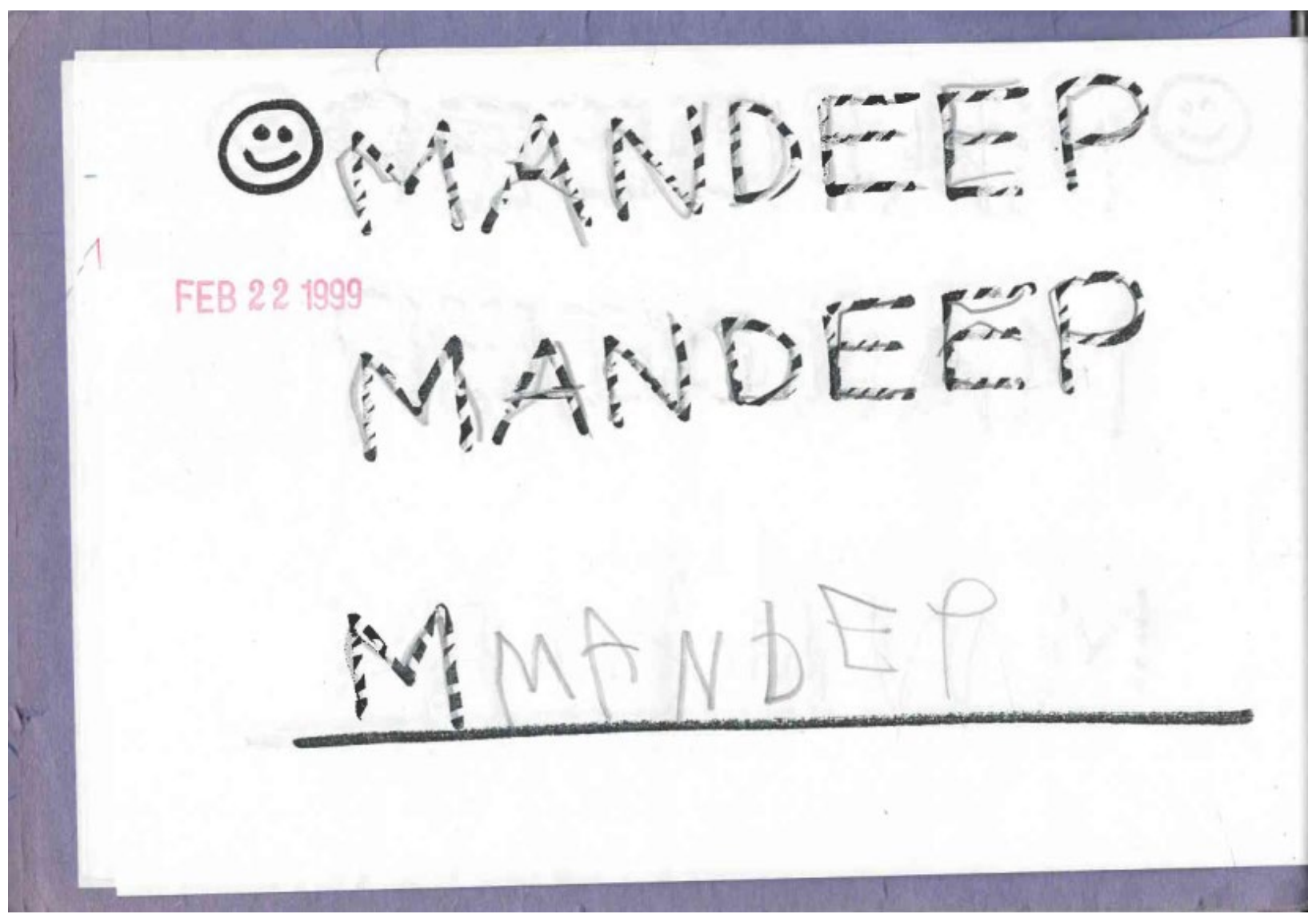

Mandep

My mother had given me a little booklet on the Punjabi alphabet.

It had letters beside pictures and space for me to trace. I would think 'What's the point?" I’m never going to write anything in Punjabi anyway. My mother saw that I was uninterested in filling out the workbook so she wrote down my name in Punjabi using little dashes just like the picture above. I traced a few letters and gave up. I didn't need to know this. Some years later somebody asked me how I would 
write my name in Punjabi. I didn’t know. I had to google it. How embarrassing. How could I not know how to write my name?

Names are an important part of how we identify ourselves. I imagine that for most people the act of giving out their name is done without a second thought. For me, however, it is a bit more of a process. My experiences compel me to select my names very carefully depending on who I am sharing them with, and the context within which I am sharing. In this paper you will find multiple names that I use to identify myself. You can find one of my names on the first page of this paper: Mandeep. It is the name written on my passport, my birth certificate, diploma, and other documents. It is my legal name (or rather the closest that my parents could spell it using the English alphabet). There are people who may not know me by Mandeep, instead they may know me by भठटीय (Mandeep), Mandy, or मक़ (Mannu). My names were either given to me, chosen by me, or a combination of both. These names are a way that I cope with the challenges of assimilating into the dominant culture.

As a South Asian child of immigrant parents, I continuously negotiate my values, beliefs, and identity between two very different cultures. As someone whose ethnicity may not be apparent through my physical features, the use of my names gives me the ability to either show or hide aspects of my culture and ethnicity. Throughout my childhood and youth I have found myself gravitating towards names that mask my ethnic identity to avoid discrimination. I have heard stories from my parents of the discrimination they face as immigrants and it is unfortunate that even today I have stories of my own, some of which you will encounter in this paper. In a country like Canada where multiculturalism is said to be celebrated, we can come across people whose ethnic names have origins from all over the world, including South Asia. In 
2016, there were over 1.1 million South Asians living in Ontario alone (Statistics Canada, 2017a). Although South Asians represent a large portion of Ontario's population, there remains the context of living in a dominant Western culture. When their names do not conform to the dominant culture, South Asians have been marginalized through racist microaggressions in the form of renaming (for example, mispronunciations and alterations of their names) that dismiss all meanings that their given name represents (Kohli \& Solórzano, 2012). As a coping response to these microaggressions, some South Asians attempt to assimilate into the dominant culture through renaming practices such as adopting a white name, using nicknames, and using an anglicized pronunciation of their name (Goodnight, 2017; Kohli \& Solórzano, 2012). The names that South Asians can use to identify themselves may also change depending on their relationships with place, the spaces and places that hold meaning (Cresswell, 2008). If a person feels that they do not belong in a place because of their name, they may change it to assimilate to the dominant culture in an attempt a sense of belonging (Cresswell, 2008; Goodnight, 2017; Kohli \& Solórzano, 2012). My experience with renaming and shifting cultural identity gives me a unique perspective on this topic. Throughout my childhood and youth I have had a very complicated relationship with my names and with whom and where I felt comfortable using them. I have heard stories of renaming experiences from friends, family, and strangers in the South Asian community. In this paper, I share mine.

This paper explores the significance of my use of different names and why I chose and continue to choose these names and is guided by critical race theory $(C R T)$ and Desi critical theory (DesiCrit). CRT stems from critical theory which asks us to evaluate and critique culture and society to understand how power structures control all thought (Nolan et al., 2013). CRT takes a transformative approach that goes beyond simply understanding an issue; it seeks to bring 
about change (Delgado \& Stefancic, 2017). There are six main tenets in CRT: 1) ordinariness; 2) material determinism; 3) social construction; 4) differential racialization; 5) intersectionality; and 6) voice-of-colour. The first tenet of ordinariness argues that racism can be difficult to address because a great deal of it is covert. More blatant acts of racism are easier to identify and perhaps easier to address (Delgado \& Stefancic, 2017).

In my experience, both covert and overt experiences have been difficult to address. I do feel less doubt about my experiences when they are more overt. Then there are those experiences that toe the line. Somewhere in between covert and overt. Perhaps they would fall more in line with covert at the time but the racism can become glaringly obvious in hindsight. Reading over some of my narratives (including those that I have chosen to keep private) I think "Why didn't I call them out? Why did nobody else?"

The tenet of material determinism recognizes that racism can be advantageous for both elite and working-class white people, making the act of addressing racism undesirable (Delgado \& Stefancic, 2017). The tenet of social construction and differential racialization are linked closely. Social construction identifies racism as a social construct that focuses on differences (Delgado \& Stefancic, 2017). These differences are not based on any true biological facts and are used to create false labels and stereotypes that can change depending on the views of society. The tenet of differential racialization addresses how different minority groups are racialized at certain times due to the needs of society. It is the social construction of race that allows such changes to be made and attributes assigned to different groups at different times. The tenet of antiessentialism describes how identities can be intersecting and overlapping. It addresses the fact that there can be conflicts within these overlapping identities. The final tenet, voice-ofcolour, calls for minority groups to centre their voices by sharing their stories and experiences of racism with the dominant culture (Delgado \& Stefancic, 2017). 
DesiCrit draws from CRT as it focuses on the racial ambiguity of South Asian Americans (Goodnight, 2017; Harpalani, 2013). Racial ambiguity allows for South Asians to make a "variety of claims to racial statuses" (Harpalani, 2013, p. 180). It also allows for others to assign different racial statuses on South Asians depending on what they identify them as through their portrayed and perceived attributes. Claiming and assigning different racial statuses categorizes people, opening them up to stereotyping that goes along with each classification (Harpalani, 2013).

Both CRT and DesiCrit influenced the way I look at race and are used as a tool in my research to help deconstruct how white supremacy plays a role in renaming practices. Another tool used in my research is my writing. Throughout this paper you may not find the usual headings and structure you may be so used to. Instead I blend together my experiences, literature, and discussions into four layers of relationships to guide my analysis. In my analysis I have also included many voices represented by different fonts. My paper speaks of taking on multiple roles and identities as a way of coping with challenges with my names and identity. Similarly, and in this paper, I use multiple voices that are spoken here in different fonts to present experiences from my past, my academic perspectives, and my thoughts as I author this paper.

Narrative pieces will be presented like this. This voice and corresponding font recalls stories from my childhood and youth relevant to my name-based and identity-forming experiences. It is distinct from writing that more closely follows the

traditional academic writing genre that has bound us as a framework to fit into as we were taught how to write papers. This voice reflects writing that more closely resembles what many would typically identify as academic, although it too is a product of my subjectivity. Across both types 
of text you will encounter another voice through marginalia. It can appear in short bursts (inside the text such as this) or

as longer trains of thought such as this. These allow me space to add comments as I read and write my work, similar to how someone would mark up a book. These spaces are not reserved solely for me. They are spaces for you too to break away from the text and allow your own thoughts to come through. I invite you to add your own marginalia (comments, critiques, and doodles too!) as you read and reflect.

They allow me to share my experiences, findings, and different thoughts and perspectives as an added level of analysis. As a result of writing my paper in an untraditional manner, before we delve into the layers we must first interrogate why I was compelled to write in such a way. 


\section{Modus Operandi}

Given my interest in understanding the deeper meanings behind my lived experiences (Creswell, 2018), this study is guided by a qualitative rather than a quantitative approach to conducting research. A quantitative approach would only allow me to represent my data in numbers (Tewksbury et al., 2009) and the data from my life experiences cannot be easily quantified. Understanding my personal experiences and thoughts requires an analysis different than numerical data, making a quantitative approach unable to accurately capture the unique and complex meanings behind my name-based experiences (Creswell, 2018; Queirós et al., 2017). A qualitative approach allows me to conduct research in a way that captures my voice and allows me to collect rich data to explore the complex topics of racism and identity in depth (Creswell, 2018).

\section{Colonial History of Investigating the Other}

The development of the qualitative research approach can be traced back to the $17^{\text {th }}$ century where its origins can be seen in ethnographic research conducted by early sociologists and anthropologists (Lockyer, 2012). While ethnographic work is now identified as a research strategy that draws from observations and interviews to study understand a phenomenon within social and cultural groups from the perspective of their participants (Creswell, 2018; Kramer \& Adams, 2017), this has not always been, and arguably is still not, the case. In early ethnographies, westerners focused their research on observing and understanding groups of people who they considered to be the "primitive" Other, which could also be interpreted as nonwhite (Lockyer, 2012; Vidich \& Lyman, 1994). This fascination with the Other only grew with the cognizance of Indigenous peoples in what was then labeled the New World (Vidich \& Lyman, 1994). The existence of Indigenous peoples was a mystery to Christian explorers who 
were unable to explain the presence of these peoples within their own existing religious doctrine on the origin of humans. The inability of religious doctrines to explain such diversity amongst peoples and cultures led to research influenced by colonialism. Research on the Other was written from a colonial perspective that viewed the Other as their opposite to justify their need to "civilize" them through indirect rule (Vidich \& Lyman, 1994).

Later ethnographies in North America continued to construct Indigenous peoples as the Other and considered research on them as a "window through which the prehistoric past could be seen, described, and understood" (Vidich \& Lyman, 1994, p. 30). Following the Civil War when the cultural and religious diversity of the United States became a threat to the homogeneity of white American Protestants, efforts were made to motivate the assimilation of those who were neither white nor Protestant (Vidich \& Lyman, 1994). These assimilation efforts included implementing surveys to identify individuals by their denomination, nationality, and race. This sparked the first qualitative community study by W. E. B. Du Bois, who conducted 5,000 interviews with Black immigrants to improve the image of Black Americans.

In the early $20^{\text {th }}$ century, ethnography became recognized as a research method by the University of Chicago's Department of Sociology and later by other institutions. Imposing Christian values was no longer the sole motivation for ethnographic research; instead and among other purposes, ethnographic studies were conducted to understand assimilation theories and race relations in diverse communities (Lockyer, 2012; Vidich \& Lyman, 1994). Following the 1960s and when ethnographic researchers themselves diversified, ethnographies began to move away from research focused on assimilation (Lockyer, 2012). From the mid-1980s onwards, postmodernism and poststructuralism changed the way that previous qualitative research is understood and how future qualitative research would be conducted. Qualitative researchers now 
began to understand the importance of their own role within their research and how their own identity affected their work (Lockyer, 2012). The rigor of previous ethnographic research that saw itself as "an unmodified and unfiltered record of immediate experience and an accurate portrait of the culture of the "other"' was challenged (Vidich \& Lyman, 1994, p. 41).

The history of qualitative research, and in particular, ethnography, is very problematic because of how its colonial roots constructed inaccurate images of the so called Other. Understanding the origins of the qualitative and ethnographic approaches are important because they allow us to realize the significance of reflexive work and the role of the researcher. This is particularly important in my research which follows an autoethnographic approach as it uses my personal experiences to understand social and cultural phenomena (Ellis, et al., 2011). I chose to write this research as an autoethnography because of my interest in sharing an insider perspective of my name-based experiences and the centering of my voice as a minority (Anderson, 2006; Delgado \& Stefancic, 2017). This paper steps outside of traditional academic writing and allows me to speak to my emotions, making my research accessible to a wider audience beyond the academy (Adams et al., 2015). The roots of autoethnography are grounded in autobiography and ethnography and it draws on the personal narrative aspects of autobiographies and the cultural narratives of ethnographic work (Lapadat, 2017). An autobiography is a form of writing in which the author presents to the reader their own life experiences (Marcus, 2018). It offers unique, subjective perspectives into the lives of people and the times that they lived in. This genre of writings has at times included more non-traditional writing, such as poetry (Marcus, 2018). As detailed above, ethnographic work invites researchers to immerse themselves in other communities to research and analyze a phenomenon from their participants' perspectives (Creswell, 2018). 
Ethnographic and autoethnographic inquiries are valuable because they allow for detailed descriptions of people and their experiences rather than giving a generalized description of groups (Vine et al., 2017). These methods require researchers to be deeply engaged within the communities they are studying for long periods of time. It allows for a higher level of familiarity with the community and topic, leading to more accuracy in the study (Vine et al., 2017). Autoethnography can deepen understandings of individual experiences rather than generalized experiences, which is important because the "[h]uman experience is chaotic and messy, requiring a pluralism of discursive and interpretive methods" (Spry, 2001, p. 727). Unlike ethnography, in my autoethnography I am not spending a few years engaging with a community and writing about what I found, I am living it. I am the very subject I am researching (I guess I would be an expert on myself?).

\section{Believing In Me}

Traditional methods of research have various ways of measuring the trustworthiness of qualitative research. With autoethnography, where I am writing about my subjective truths and experiences, it gets a little tricky (How am I to prove to others that my experiences are truthful?). Positivist perspectives see autoethnographies as unable to meet these criteria (Denzin, 2014). Ellis et al. (2011) use the traditional measures of reliability, generalizability, and validity and transform them to fit autoethnographies. Their version of reliability asks whether it is possible that the writer has experienced what they claim to have experienced. Validity asks whether the reader feels that the narratives presented to them are truthful. Generalizability asks the readers whether the narratives are relatable to their own experiences or of people that they know (Ellis et al., 2011). 
Triangulation is often applied as a means of validating research. It requires the use of either multiple methods, investigators, theories, or data (Carter et al., 2014). Richardson offers us a postmodernist alternative to triangulation: crystallization (Richardson \& St. Pierre, 2005). Unlike a triangle, a crystal has various shapes and sizes that can change depending on the angles you look at it. This visualization offers a way to deconstruct the idea of validity. Through each angle of the crystal that we look at, we see different knowledges on the same topic illuminated (Richardson \& St. Pierre, 2005). Now keeping in mind that "there is no single truth" (Richardson \& St. Pierre, 2005, p. 963), my research can be seen as valid because it provides one version of the truth, one angle of the crystal (Richardson \& St. Pierre, 2005).

\section{Situating Myself and Meanings}

Within my autoethnography, I locate myself within multiple groups and communities that have meanings beyond what I interpret from them. This can be problematic as I write from multiple perspectives including South Asian, female, Canadian, and Sikh, to name but a few. Although I write as someone who can be identified and who self-identifies as a part of these groups, the diversity within each group makes it so that my experiences and the meanings that I draw from them cannot be generalized to other members. They are specific to me. This impossibility of generalization applies to others who are implicated in my writing. Although I am the only participant from whom data is collected, non-active participants are included by proxy through their presence in my name-alteration related experiences and resulting identity understandings. Their perspectives and the meanings they place on their presence in my namealteration related experiences may not be reflected in my writing. Although there may be people who are able to relate to my experiences, it is important for me to emphasize that my experiences 
are specific to me, especially when I think about the colonial history of ethnographies that have been used to generalize biased perspectives (Vidich \& Lyman, 1994).

\section{Writing as Data Collection \& Analys is}

My research does not adhere to the typical presentational role of writing in scholarship. Instead, my writing takes up many roles and is also used as a method of inquiry to both collect and analyze data (Richardson \& St. Pierre, 2005). I gather data from my memories, which have not necessarily been written down or documented previously. These jottings consist of diary entries written once I began my research. They were written selectively and retroactively so that more significant data could be presented (Ellis, et al, 2011). This process took place throughout the study as I recalled more experiences from my childhood and youth. One of the important parts of writing my diary reflections was acknowledging that memories are imperfect and incomplete, making it impossible to accurately replicate my experiences (Ellis et al., 2011). This was important to keep in mind as I wrote so that I was not writing more than I was actually remembering. While they may not be written word for word, I have represented my lived experiences in a way that is significant for me through my narratives. Some experiences appeared so vividly to me in my remembering, allowing me to replay them in my head like a movie (unfortunately the most memorable ones were also some of the worst), whereas with others, I could only remember what was said. Therefore my narratives vary in length and in detail depending on what I was able to recall.

As far back as I can remember (Perhaps some time in high school? Or was it even earlier than that?), whenever my class was assigned a paper someone would ask, "Can we use 'I'?" Rarely did we ever get permission to do so and even if we did it was recommended that we use it sparingly. As I began writing at university, this question came up less and less often. I 
agree with Laurel Richardson who asserts that the restraints put upon qualitative writing to fit into a strictly scientific format can in turn make it incredibly uninteresting (Richardson \& St. Pierre, 2005). In my writing, I attempt to escape these constraints, blurring the lines between genres of writing with the inclusion of my own voice. This poststructuralist approach offers a way to view my writing and myself as inseparable. My subjectivity is present throughout this research (how can it not be in an autoethnography?) because my experiences are my greatest motivation and inspiration for choosing to write on the topic of names and identity (Richardson $\&$ St. Pierre, 2005). Names and identities are so personal, complex, and intimate; it feels impossible to write on them without including myself in the process. This is done not only through my narratives but also throughout the entirety of this paper.

Although my writing is organized into thinking about community, family, friends, and self, my research does not use coding to analyze data. Analysis occurred throughout my writing process as "thought happen[s] in the writing." (Richardson \& St. Pierre, 2005, p. 970). My analysis itself has influenced the organization (or rather dis-organization?) of my paper. It began first with the difficult task of pulling apart my narratives into different layers of reflection on community, friends, family, and self. They offered a different angle (like a crystal) in which my narratives could be analyzed. These layers are connected in multiple ways and overlap each other because my experiences do not fit neatly into each category. Their separation into layers can be described as almost an illusion, serving only as a tool to analyze my experiences. As I wrote my narratives I simultaneously analyzed them, placing them in the layer that I felt would best suit its analysis. Up until the end, narratives were being added, revised, or removed. They were all typed up into one long document. I continue to add them whenever I recalled an experience. Once I had pages and pages of writing I reread them and added as much detail and 
accuracy as possible. I sorted them all out into the reflective layers within the document. Once that was completed I printed and cut out all of my narratives and began sorting them once again. There were many I had to think twice about. Some of the organization I had done previously suddenly did not make sense anymore. Near the end I had four piles sitting on my floor and some loose pages sitting in between. They were eventually all sorted and I changed my word document to reflect that. From there, I let literature, thoughts, feelings, and reflections guide my writing.

\section{The Ethics of Non-Active Participation}

Although my writing focuses on me, it remains inclusive of people who were a part of my name-alteration related experiences and resulting identity understandings. This made it important to gain approval from the Ryerson Ethics Board (2020-171) and comply with the TriCouncil Policy Statement on ethical research involving humans. Although not involved in data collection, the presence of other people in my writing puts them in the role of a non-active participant. They are participants by proxy only but it remains important that $\mathrm{I}$ have their consent. As an active participant and researcher, I am aware that the experiences that I chose to share are voluntary and there are no consequences for me to choose not to reveal experiences that I may not want others to know. I shared with my non-active participants that participation in the research was voluntary and that there were no consequences for non-participation (see Appendix A \& B). I have also shared that if at any time during the research they wished to withdraw their consent for participation in any or all of the research, they were free to do so without consequence. The letters of consent for non-active participants (see Appendix C) outline the voluntary nature of participation and the right to withdraw.

Given the pre-existing relationships that I have with my non-active participants, it is also important to consider relational ethics. Relational ethics requires me to act in ways that respect 
and value the relationships between myself and my non-active participants (Ellis, 2007). What I communicate to my non-active participants through my writing may disclose thoughts and feelings that could unsettle our relationships. The consequences of conducting autoethnographic research can alter my relationships with and the relationships between non-active participants (Ellis, 2007; Ellis, et al., 2011). How can I write in a way that is truthful and meaningful while also taking into consideration the well-being of those implicated in my writing? (Ellis, 2007; Lapadat, 2017). This is one of the questions I continuously asked myself to fulfill my ethical responsibilities to my non-active participants and my pre-existing relationships with them as well as to maintain honesty in my writing (Ellis, 2007). I offered samples of my writing relevant to each non-active participant so that they could exercise their right to ongoing consent of my representations of them. 


\section{Community}

I thought about what kinds of names I would give to my future children. I didn't want their names to be too traditional, but I also didn't want their names to be so different from the rest of their South Asian community. Is there truly any middle ground? Either way, there will be one group that sees them as different.

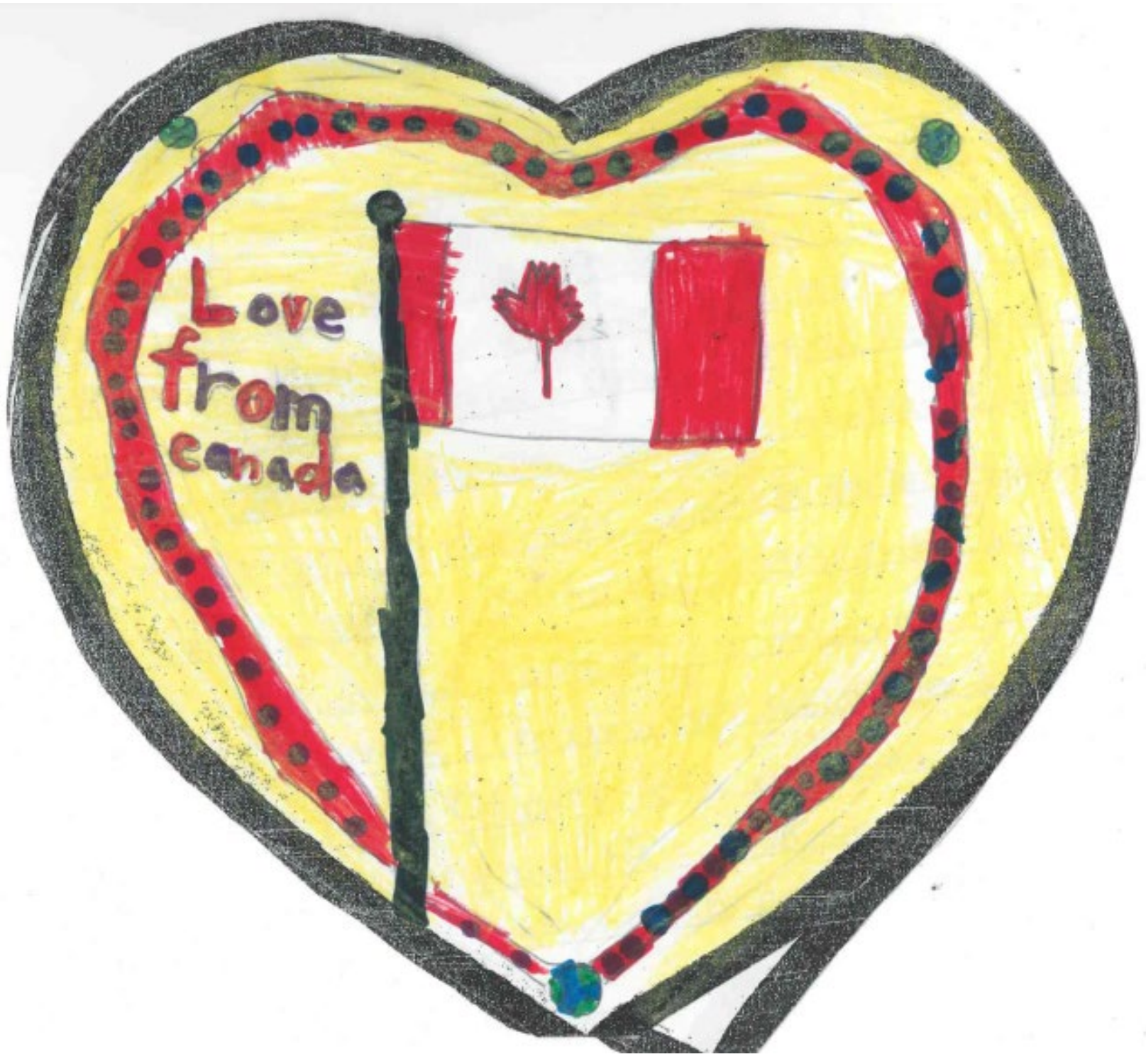

Love From Canada 
Inside this little booklet created at school in 2002, I wrote a letter to a pen pal (I don't think it was even sent...otherwise I wouldn't have it...). My class was asked to describe Canada in our letters. Inside this booklet, my description of Canada is as follows: "Did you know that Canada is across the world from where you live? Canada is in North America. Canada is a cold country and we get lots of snow in the winter. Canada is the second largest country in the world. Canada is a multiculture [sic] country. Canada has ten

provinces and three territories."

\section{The Three Pillars of White Supremacy}

Canada has curated for itself a national identity of a cultural mosaic, one that is so widely embraced without question that its history of racism and white supremacy remains well hidden (Hogarth \& Fletcher, 2018). Now, perhaps more than ever before, Canadians are being called to remember and listen to the shared histories of our country and act to upset and reimagine a cultural mosaic that truly and deeply embraces diversity and difference while also upsetting social, economic, racial, and cultural hierarchies so entrenched in Canadian life. Andrea Smith's (2006) Three Pillars of White Supremacy framework can allow for the logic behind Canada's silenced history to be revealed. The framework outlines how white supremacy is held up by the three logics: 1) slaveability/anti-Black racism; 2) genocide; and 3) orientalism. The first pillar is the logic of slavery and is rooted in capitalism. It identifies Black people as "inherently slaveable" (p. 67) and places them at the lowest rung of a racial hierarchy that perpetuates antiBlackness (Smith, 2006). In Canada, slavery existed for over 200 years and laid the foundations for the dehumanization of Black people and the perpetuation of anti-Black racism (Maynard, 2017). Even after the abolition of slavery, the meanings of what it meant to be Black had been 
altered to align with "subservience, criminality, lack of intelligence and dangerousness" (p. 31). This devaluation of Black life has been perpetuated through racial segregation and increased policing where Black people are recognized as dangerous and inferior to white people (Maynard, 2017). Ray et al. (2017) argue that the systems that produce and reproduce these racial inequalities do not disappear, but rather evolve.

As I write this paper I struggle with the idea that I am writing on topics of colonization while living on colonized lands (Tuck \& Yang, 2012). How can I write about feeling a sense of belonging to the very land where Indigenous peoples have been told they do not belong? As a non-white settler I cannot ignore my role in settler colonialism. How have I made moves to innocence (Tuck \& Yang, 2012)?

The second pillar of white supremacy is the logic of genocide and stems from colonialism (Smith, 2006). This logic asserts that Indigenous people must disappear to allow European settlers to declare themselves to be the rightful owners of Indigenous lands (Smith, 2006). The colonization of Indigenous lands now known as North America began with the arrival of Christopher Columbus in 1492 (Maynard, 2017). Created from a series of statements from the Pope in the 1400s, the Doctrine of Discovery was used to legally justify the colonial project in Canada (Assembly of First Nations, 2018). It allowed Christian explorers to claim lands for their monarchs if they were not already owned by other Christians (2018). Thus began the Canadian history of Indigenous genocide and slavery. Canada's naming of Indigenous peoples as "savages" served as their justification to see them as lawfully inferior and undesirable (Hogarth \& Fletcher, 2018). Canada's government used oppressive laws and policies to facilitate the erasure of Indigenous peoples and their communities through assimilation, genocide, and slavery (Hogarth \& Fletcher, 2018; Tuck \& Yang, 2012). The violent effects of colonization on 
Indigenous peoples are still present today. The colonial project in Canada is continued today through settler colonialism, where there is no separation between the colony and the colonizers. The colonizers came and then never left, asserting that these lands are their home and claiming sovereignty over stolen land (Tuck \& Yang, 2012).

The third pillar of white supremacy is orientalism and is anchored in war (Smith, 2006). This logic uses Edward Said's definition of orientalism--the West views themselves as opposite and superior to the Orient--and applies it outside of the Orient (Said, 1978; Smith, 2006). Orientalism views people as "permanent foreign threats" (Smith, 2006, p. 68) no matter how long they have been living in the West. Although Smith applies this logic to anti-immigrant sentiments in the United States, the same logic can be applied in a Canadian context. Specifically, in British Columbia, white Canadians adopted stereotypical perceptions of Chinese, Japanese, and Indian immigrants and expressed hostility towards these groups (Ward, 2002). Immigrants were seen as unassimilable and threats to the health, livelihood, and homogeneity of white British Columbia. Immigration from countries including China, Japan, and India was seen as an invasion, leading up to the 1907 Asian Riots in Vancouver (Ward, 2002). Although the movement had started in the United States, it reached Vancouver where a white supremacist group attacked Japanese, Chinese, and Indian businesses and marched to City Hall, where they called for a white Canada (Mucina, 2019; Ward, 2002) The riot and anti-immigrant sentiment led to racist policies on immigration and employment (Ward, 2002).

When I introduce myself I make a quick decision in my head about how I want to represent myself to others. 
I have to quickly take in my environment. Where am I? Who am I with? How long will I be interacting with them?

All of this just to decide which of my names to give.

It makes me sad to think about how often I fantasized about growing up and changing my name.

I didn't expect it to be something I would end up changing multiple times a day.

\section{Picking a Label}

Data from the 2016 census showed that over 1.9 million people in Canada could trace their origins to South Asia (Statistics Canada, 2017b). Canada's 2016 census referred to South Asians as people whose origins are Bangladeshi, Bengali, Bhutanese, East Indian, Goan, Gujarati, Kashmiri, Nepali, Pakistani, Punjabi, Sinhalese, Sri Lankan, Tamil, or South Asian (Statistics Canada, 2017a). However, Ghosh notes that there is little consensus on the geography of South Asia (2013). Afghanistan, Myanmar, and Nepal are just a few examples of countries that Canadian scholars have both included and excluded as a part of South Asia. Ghosh goes on to critique the use of the term South Asian as being problematic in Canada because it homogenizes diverse communities and ignores differences in cultures, histories, languages, and religions. This homogeneity supports the illusion that there exists a single South Asian culture 
rather than the multiple cultures that the term encompasses (Ghosh, 2013). Although the use of the term South Asian is problematic, many people in North America continue to adopt it as a diasporic identity (Carsignol, 2014; Ghosh, 2013). Alternatively, other identifiers such as Desi and Brown have been adopted by some individuals in place of South Asian as more appropriate terms (Carsignol, 2014). The word Desi is derived from the Sanskrit word deśha (meaning country) and is meant to describe people who originate from the homeland (South Asia) (Carsignol, 2014). It has been adopted by many second-generation South Asian youths in the United States and Canada, limited to those whose origins are from the Northern parts of the Indian subcontinent (Carsignol, 2014; Maira, 2002). Other terms such as Masala have been used not to refer to people but to products of creativity (for example, movies and dance) inspired by the multiple cultures originating from the Indian subcontinent (Carsignol, 2014). Masala is a Hindi word that can be translated into blend of spices (Ramsaran \& Lewis, 2018).

The use of Brown has only recently emerged in North America as an identifier and is particularly popular among youth (Carsignol, 2014; Harpalani, 2015). Although Brown identity is labeled by colour, skin colour is not an important factor for people who claim this identity (Harpalani, 2015). This could be due to the great variance in skin tones amongst South Asians. Colour has often been used in place of race in North America, where both white and Black have been used as formal colour-based racial categories. Historically in the United States, South Asians have been inconsistently classified into racial categories, seen as white, Non-white, Black, and Brown (Harpalani, 2013). In the early twentieth century, Canada's census formally used white, red, black, and yellow as formal colour-based racial categories (Canada, 1901). Brown was not used as a formal colour-based racial category, but it was still used to racialize immigrants from India (Canada, 1901). There were inconsistencies here as well where 
immigrants from India were racialized as black and brown and Japanese people were described as brown and yellow (Backhouse, 1999). These differences can be attributed to the racially ambiguous identities and differential racialization of South Asians in the Black/white Manicheanism of the United States and Canada (Delgado et al., 2017; Deliovsky et al., 2013; Harpalani, 2015). Deliovsky et al. (2013) argue that it is important to not view North American race relations as a Black-white binary, but rather as a Manicheanism; a framework that envisions the world through the dualism of good and evil. This Manicheanism stems from western European cultures that attributed symbolic meanings to skin colour. It transferred meanings of goodness and light to whiteness and meanings of evil and dark to Blackness. The analysis of this Manicheanism does not support a simple binary, but rather asserts a structure of polarity that other racial groups have been measured against to be ranked in a hierarchy (Deliovsky et al., 2013). To understand racial ambiguity, it is important to explore formal and informal racialization as well as race/ethnicity performance. Formal racialization includes racial classifications created by an authority such as a government (Harpalani, 2013). On the other hand, informal racialization is based on the social meanings of race, including physical features and symbols that can be assigned different racial stereotypes. Race/ethnicity performance is any behaviour, physical attribute, or symbol that "communicates racial or ethnic identity or status" (Harpalani, 2013, p. 21).

I have inconsistently and situationally referred to my ethnic origins as Asian, South Asian, Punjabi, Brown, Canadian, and Desi. I have only used Desi a handful of times, often when somebody else uses it first. Desi means homeland and is used to describe a shared identity between South Asians originating from the northern parts of the Indian subcontinent (Carsignol, 2014). It is meant to be an identity that spans across borders, linking the Desi diaspora to Desis 
living in the subcontinent (Radhakrishnan \& Koshy, 2008, as cited by Carsignol, 2014). I never felt comfortable referring to myself as Desi because I did not feel connected enough to Desi culture, not when I'm in Canada and not when I'm in India. The term seems to encompass so much that it doesn't leave room for elements of my identity that do not fit into Desi culture. I would likely be referred to by Desis as an American Born Confused Desi (ABDC) (Harpalani, 2013); Desi, but not quite. I find that calling myself Asian does not fit quite right because of how Asian identity has often been centered on East Asia (Harpalani, 2013). When I did use it, it was contested and people would say that I was South Asian, arguing that technically I was Asian but not quite. Using the term South Asian had once made me feel connected with others who would use the same identifier. I later found the term to be too broad, almost meaningless. South Asian can be seen as a product of colonization, internalized and used situationally by South Asians as a diasporic identity (Ghosh, 2013). The geographic boundaries of South Asia have been in flux from early colonization and more contemporary decolonization to create South Asian as an ethno-racial identity (Ghosh, 2013). The identifiers I feel most comfortable using are Punjabi and Brown. Punjabi feels more personal and familiar to me. I have been to Punjab and, for the most part, I can speak the language. I have family in Canada and Punjab who would identify as Punjabi. I label myself as Brown when I want to place myself in a larger collective group. Brown gives me a voice in North American race relations (Carsignol, 2014).

I often use Mandy when I'm speaking to someone I would be interacting with briefly, like giving my name for an order at Starbucks. It is a very short interaction so I am unlikely to be questioned. If I tried to do that with someone I would know for 
longer, I would eventually get questions about my ethnicity or my "real name." I don't like the name Mandeep because I get questioned about it being a male name or people comment on the fact that it contains the words "man" and "deep." When I introduce myself to someone now it is usually with, "Hi, my name is Mandeep, but you can call me Mandy." In the same sentence. In the same breath, I would rename myself. Over and over again. I can't always just introduce myself as Mandy without the explanation because I'll get questioned for using a name that I don't "look like" I would have.

Through the social meanings of race, South Asians can perform race/ethnicity. The use of racial ambiguity allows for South Asians to make claims to different racial statuses to ease their navigation of the contexts in which they are in (Harpalani, 2013). Racial ambiguity allows South Asians to make claims to whiteness, making it easier for them to assimilate into the dominant culture. These claims to different racial identities become "a privileged resource that can be allocated and withdrawn, [and] that can be claimed and contested" (Harpalani, 2013, p. 22). As a result of claiming Brownness, South Asian Americans (and arguably South Asian Canadians) can instead create a racial identity for themselves distinct from but similar to the racial identities of Black and white (Harpalani, 2015). Related to the concepts of racial ambiguity and claiming whiteness is the term passing. Passing, which has also been referred to as racial passing, is when a person's appearance allows them to take on a different racial identity to change others perceptions of them (Kennedy, 2001). The term passing in American history has been used to describe the "assumption of a fraudulent 'white' identity by an individual culturally and legally 
defined as 'Negro' or black by virtue of a percentage of African ancestry." (Ginsberg, 1996, p. 2). It was used to describe how racial boundaries were crossed to escape oppression (Broady et al., 2018). Considering America's history of slavery and racial segregation, it is not surprising that passing has been primarily associated with Black people who had the ability to claim

whiteness. Although passing could be used in my research to describe how I used my appearance and names to alter how I was perceived to gain benefits of whiteness, much of the literature and discussions on passing focuses on Black to white passing as a means of survival and escaping oppression (Broady et al., 2018). I instead focus on racial ambiguity because of the differential racialization of South Asians throughout history and how this has been used by myself to make claims to whiteness (Harpalani, 2013).

\section{Orientalism \& Whiteness}

One of the ways that the dominant culture in western countries can perpetuate ideas of their cultural superiority to others is through whiteness, an invisible social process that has been used by the dominant culture to maintain power over minority groups (Yee, 2005). One of the mechanisms through which whiteness operates through is naturalization and this allows the positioning of white people as the norm (Yee, 2005). Naturalization makes it so that white people never have to define themselves yet makes clear the differences of those who are not white, or Others. (Chen, 2017; Yee, 2005). Noting the differences of the Others creates the perception that white people are not different from non-white people, but that non-white people are different from white people (Chen, 2017). Non-white people, therefore, be seen as Others in white-dominated places (Said, 1978).

One of the ways that white people have positioned themselves as superior is through Orientalism, which was discussed previously in the context of Andrea Smith's (2006) Three 
Pillars of White Supremacy framework. Orientalism is a colonialist construction of knowledge of people and cultures from the Middle East and Asia (the East) and how it shaped the identity of people from Europe (The west) (Said, 1978). Edward Said explored Orientalism by deconstructing colonial literature to show how multiple disciplines throughout history have been used to construct representations of the East. He addressed a relationship between knowledge and power by analyzing European texts that constructed knowledge about the Orient and disseminated it to the then labeled Occident, now the west (Said, 1978). This knowledge was often false and inaccurate but was nevertheless taken up to create a binary view of the Occident as good and the Orient as bad and these dichotomous views of the East and west influenced the construction of the Other (Ashcroft \& Ahluwalia, 2001; Said, 1978). The west placed value on themselves and dominated the East through Othering them, devaluing them through the creation of in and out-groups (Staszak, 2009). An in-group refers to a group in which an individual belongs and out-group is a group which they do not belong to. The out-group only exists to reinforce in-group identity that sees itself as opposite and superior (Staszak, 2009). These groupings allowed the Europeans in the West to create their identity based on how they differed from people living in the East, situated in their inaccurate constructed knowledge of them (Ashcroft \& Ahluwalia, 2001; Said, 1978).

Europeans used whiteness to frame the East in a position inferior to their own without being questioned or contested (Said, 1978; Yee, 2005). This transnational context is important for understanding how knowledge and power have been deployed internationally and how they continue to be used around the world, working to assert and maintain white supremacy (Iftikar \& Museus, 2018). Although Said used past literature to explore the construction of knowledge, the same ideas can be applied today to explain the knowledge constructed around South Asians 
(Said, 1978). Currently, literature, media, pop culture, laws, and policies can play a part in constructing the image of South Asians (Harpalani, 2013; Said, 1978). The constructed image of South Asians exists in multiple binaries including those who are Fresh off the Boat (FOB) versus American Born Confused Desis (ABCD) (Harpalani, 2013; Said, 1978). Another binary is the economic divide, where South Asians are associated with success (for example, as doctors and engineers) versus the image of South Asians as unsuccessful (for example, as taxi drivers and convenience store clerks) (Harpalani, 2013). The dominant culture's power to create and maintain these binary groupings of South Asians is an example of how they use whiteness to retain power (Harpalani, 2013; Yee, 2005). The dominant culture has the ability to racialize South Asians differently (Sometimes I am seen as a model minority and sometimes as a perpetual foreigner) in order to stay in power (Museus \& Iftikar, 2013; Yee, 2005). These groupings are strategically constructed to fit the needs and advantages of the dominant group (Iftikar \& Museus, 2018). Although South Asians are able to partially navigate their constructed racial identities through their racial ambiguity, their claims to whiteness can always be challenged (Goodnight, 2017; Harpalani, 2013).

I would often be questioned about my name while I was working as

a server in a diner. When I had just started, my trainer printed out a sticker that said "Mandeep" on it for my nametag. I didn't want that as my nametag. I didn't want others to know that was my name. Would my name be made fun of? Maybe they wouldn't say anything to me but they might think about it. I asked her right away to instead print out a sticker that said "Mandy." Occasionally I had some customers who would 
look at my nametag and say, "That's not your name. What's your real name?" or they would try to guess my ethnicity. "What are you? Oh, let

me guess! Are you mixed? No? Persian? No? Italian?” I always got a wide range of guesses. I used to find it amusing and even felt proud

of it. I remember almost bragging about it to others. Why was I bragging about not looking Indian? Was I happy that I looked

different? That people thought I could "pass for white?"

I slowly distanced myself from my South Asian culture because I did not see value in it. My interactions within Canada informed the ways that I viewed South Asian culture. I viewed South Asian culture through the lens of white supremacy which firmly placed it, and in turn me, in a position of inferiority (Said, 1978; Yee, 2005). I bought into this perception of South Asians that the dominant culture used their power to create (Ashcroft \& Ahluwalia, 2001; Said, 1978). I internalized these racist messages and knowledge about South Asian people and culture, and about myself (Choi et al, 2017). I found value in being seen as someone who could pass for white.

\section{Microaggressions}

The racism experienced by South Asian people has varied due to their differential racialization, the ways that they are treated based on the ever-changing views of the dominant culture (Delgado \& Stefancic, 2017; Harpalani, 2013). South Asian people can experience different forms of overt racism such as stereotyping or covert racism in the form of racial microaggressions. Racial microaggressions are a subtle form of racism that are often not 
recognized by the dominant culture to actually be racist (Delgado et al., 2017). Kohli and Solórzano (2012) argue that racial microaggressions are insults and assaults that are subtle both verbally and non-verbally, layered based on multiple aspects of identity, and cumulative. Racial microaggressions are not confined to interactions with others but are also present in interactions with environments (Sue et al., 2007).

Sue et al. (2007) identified three different themes within microaggressions: 1) microassault; 2) microinsult; and 3) microinvalidation. A microassault is an intentional discriminatory act and is the most obvious type of microaggression. For example, using racial or ethnic slurs can be identified as a microassault. Next, microinsults are subtle verbal and nonverbal acts that convey messages of contempt and disrespect towards someone's race/ethnicity and these are often not obvious to the transgressor. An example of a microinsult is not attempting to say a name because it is different. Finally, microinvalidations are actions that invalidate and diminish the importance of lived experiences of Black, Indigenous, and People of Colour (BIPOC) (Sue et al, 2007). For example, telling someone they are overreacting to a racist joke is a microvalidation. Within these themes are the nine categories: 1) alien in one's own land; 2) ascription of intelligence; 3) color blindness; 4) criminality/assumption of criminal status; 5) denial of individual racism; 6) myth of meritocracy; 7) pathologizing cultural values/ communication styles; 8) second-class status; and 9) environmental invalidation (Sue et al., 2007).

The perpetrators of racial microaggressions may not always see their behaviour as harmful or wrong, nor do they always have malicious intent (Sue et al., 2009; Wang et al., 2011). This makes it difficult for targets of racial microaggressions to call out racism within their interactions with the perpetrator without seeming as though they were overreacting (Wang et al., 
2011). Wang et al.'s (2011) study on the emotional impacts of interpreting situations and interactions as racial microaggressions and study participants included Asian Americans because of held perceptions of them as model minorities. The model minority myth originates from the Moynihan report (United States, 1965) that suggested "Asian Americans were better than Blacks but inferior to [w]hites" (Iftikar \& Museus, 2018, p. 937). It has been argued that this myth has created a divide between Asian Americans and other non-white groups (Iftikar \& Museus, 2018). The Moynihan report, combined with the media's negative and stereotypical representation of Black Americans, has moved South Asian Americans to perpetuate ideas of anti-Blackness and strive for whiteness in order to bring themselves higher up in the racial order (Harpalani, 2013; Iftikar \& Museus, 2018; Ray et al., 2017). Wang et al.'s (2011) research indicated that racial microaggressions could be related to not only race but also the target's intersecting social identities (e.g., race and gender). Study participants also expressed higher negative emotions the more they believed that their race was a factor in a microaggressive interaction (Wang et al, 2011).

Just as my names have been, my embrace of all of these identities has been, and will continue to be, negotiated by my experiences. My identities can be situational, used to maintain my sense of belonging across various relationships and environments. Racial microaggressions have played a large role in my decisions about how to identify and what names to use. If I did not feel comfortable using my ethnic name, then it was likely I did not feel comfortable sharing my ethno-racial identities. Microaggressions rooted in race have affected me to the point where I had purposefully hidden parts of my culture. As a consequence of microaggressions and acculturative stressors, I have been made to feel alien in my own land, whether that be Canada, India, or some place and space in between (Sue et al., 2007). 
Racial microaggressions can have lasting effects on an individual's emotional wellbeing (Kohli \& Solórzano, 2012). These actions can lead to internalized racism, "the conscious or unconscious acceptance of a racial hierarchy in which whites are consistently ranked above People of Color" (Huber et al, 2006, p. 200). Kohli and Solórzano (2012) label internalized racism from racial microaggressions as internalized racial microaggressions. They argue that internalized racial microaggressions can make victims "doubt their place or cultural worth in US society" (2012, p. 9). Nadal et al. (2014) have also explored the impact of racial microaggressions, finding that they can have a significant effect on the mental health of victims. Their study found that "individuals who perceive and experience racial microaggressions in their lives are likely to exhibit negative mental health symptoms, such as depression, anxiety, negative affect (or negative view of the world), and lack of behavioral control" (p. 62). Their study also showed that, although there were no substantial differences in how many microaggressions the BIPOC in their sample experienced, there were differences in the types of microaggressions. Their data indicated that Asian participants may have more experiences with microaggressions related to their environment and exoticization than Black participants (Nadal et al., 2014).

Although I have adopted so many characteristics and qualities from the dominant culture and rejected so much of my South Asian culture, I will never be seen as someone who truly belongs in Canada because I am a minority. Historically in the United States, South Asians were inconsistently put into racial categories, seen as white, non-white, Black, and Brown depending on the needs of the dominant culture to maintain its own advantage over the Other (Harpalani, 2013). South Asians have had to continuously make conscious efforts to assimilate in order to try to maintain honourary white status because their claims can always be questioned, demoting them back into the position of the Other and as a perpetual foreigner (Goodnight, 2017; 
Harpalani, 2013; Iftikar \& Museus, 2018). I rename myself repeatedly so that I can blend in within multiple places and spaces that hold meaning for me. This includes places where I feel that I belong as well as places where I feel that I do not belong (Arefi, 2004; Marcouyeux \& Fleury-Bahi, 2011). As a South Asian person born in Canada, I am stuck in a sort of limbo in a binary of belonging and not belonging. When I visit my parents' homes in India, I am a foreigner in that land, treated as a tourist (Taylor, 2015). When I am in Canada, where I have lived my entire life, there are endless microinvalidations and reminders that I am a foreigner here as well (Sue et al., 2009).

Kohli and Solórzano (2012) have argued that renaming practices are racial microaggressions because they are subtle ways of disregarding names and their related personal and cultural meanings. Renaming practices are acts of altering or mispronouncing a person's name and a person's name can be changed by themselves and/or others (Kohli and Solórzano, 2012).

\section{History of Renaming}

There are many examples throughout Canadian history where the names of people and places were renamed. In the mid-1880s, Indian Residential Schools (IRS) were used as a way to assimilate Indigenous children in a white dominated Canada (MacDonald \& Hudson, 2012). In 1920 attendance became compulsory for many children whose families were threatened with penalties for noncompliance (Macdonald, 2019). Once in the IRS, children were forced to replace their clothes for a uniform, their hair was shaved, and their names were replaced with numbers. Renaming in the IRS happened twofold. First with a temporary number, and then again once they were baptised and given a Christian name. In some cases, survivors of the IRS had 
forgotten their original name (Madconald, 2019). The IRS and their assimilation tactics were essentially meant to "kill the Indian in the child" (Young, 2015, p. 65).

Alongside the renaming of Indigenous peoples was also the renaming of their lands. Since the beginning of the colonization of Canada, the Indigenous names given to the lands were erased and replaced by European settlers to legitimize their claims to it (Team ReconciliAction YEG, 2018). Through renaming, settlers have imagined and continually reassert colonized lands as their own (Rose-Redwood, 2016). In efforts to fight colonial practices of renaming, many Indigenous peoples are currently fighting to reclaim space (ReconciliAction YEG, 2018). This process has been met with some pushback from other inhabitants who do not wish to rename the land (ReconciliAction YEG, 2018). (The land has already been named by colonizers.... Indigenous peoples are trying to change it back...)

Renaming practices have also been used during times of slavery (Palsson, 2014). Enslaved people were punished for using their own or another's enslaved person's true name. Renaming allowed slave owners to erase the history and identities of enslaved people (Palsson, 2014). It erased the ties they had with their families, contributing to what Patterson (1982) would view as a part of the process of "natal alienation." Natal alienation is a term coined by Patterson (1982) used to describe the alienation of enslaved people from all previous, current, and future family ties. They would be isolated from any and all communities (Patterson, 1982). He described renaming as one of the basic features of the ritual of enslavement that was "always [emphasis added] deeply humiliating and sometimes even traumatic, for the slave" (Patterson, 1982, p. 52).

\section{Renaming Me}


I have been renamed myself so many times and have similarly been renamed by others because of the high value that has been placed on western culture and language. The practice of renaming myself is one of the ways that I navigate my racial ambiguity because, in renaming, I have the ability to hide my cultural background (Souto-Manning, 2007). I often decide (Although it doesn't always feel like I have a choice) to use different names depending on who I am speaking to and where I am using them because of linguistic differences (Nic Craith, 2012; Srinivasan, 2019). Language is one of the biggest barriers that immigrants face when moving to a new place (Nic Craith, 2012; Souto-Manning, 2007). There is often a period of silence for immigrants who are learning a language in a new country; they cannot speak their native tongue because they will not be understood yet they are unable to speak in the language of their new home because they have yet to learn it (Nic Craith, 2012). When immigrants are in an environment where the dominant language is something other than their native tongue, their name is often mispronounced by those from outside of their linguistic community. When moving to a new place, assimilation often requires immigrants to adapt their culture, including their language, to their new context in order for them to feel a greater sense of belonging. Research has highlighted the desperation felt by some immigrants as they work to belong to their new homes and become insiders. These actions and feelings are captured, for example, in the experiences and emotions of a mother who, as part of her own immigration and assimilation process, began to mispronounce her own name and subsequently her children, husband, and friends were not able to pronounce her name (Nic Craith, 2012).

My choice of which name to use often depended on finding commonalities between my languages and the language(s) of the person I was speaking with (Nic Craith, 2012; SoutoManning, 2007). When speaking to people outside of my culture, I was able to hide my 
background by making claims to whiteness. I did this by taking advantage of my racial ambiguity and changing my name to Mandy, a name that I would consider to be my white name (Harpalani, 2013; Souto-Manning, 2007).

In the end, it wasn't only my name that changed. I began to reject so much of my South Asian culture because changing my name was not always possible and not always enough to fit in. Everything I saw in the media about my culture was negative. I would proudly identify myself as a Canadian first and made fun of others who did not fit the mold. I never questioned what I was doing. It took so long to realise how brainwashed I was.

A person who assimilates their name is often changing many other aspects of themselves to fit into the dominant culture (Jagieła \& Gębuś, 2015). Similar to the experiences of other children, the process of assimilating myself into western culture created pressures to both anglicize my name and disassociate myself from many aspects of my culture (Souto-Manning, 2007). Changing my name enabled me to hide my culture and my language, allowing me to somewhat control aspects of my identity that I choose to make visible (Peterson et al, 2015). Although I have used some names that make my South Asian culture visible, I more frequently used names and pronunciations that made my connections to South Asian culture less visible. It was important for me to feel like I belonged. I did not want to be seen as different. I wanted to be the same. 


\section{Friends}

I have had friends and peers who have called me a coconut. Brown on the outside and white on the inside. This didn't bother me at the time. I’m pretty sure I took it as a compliment.

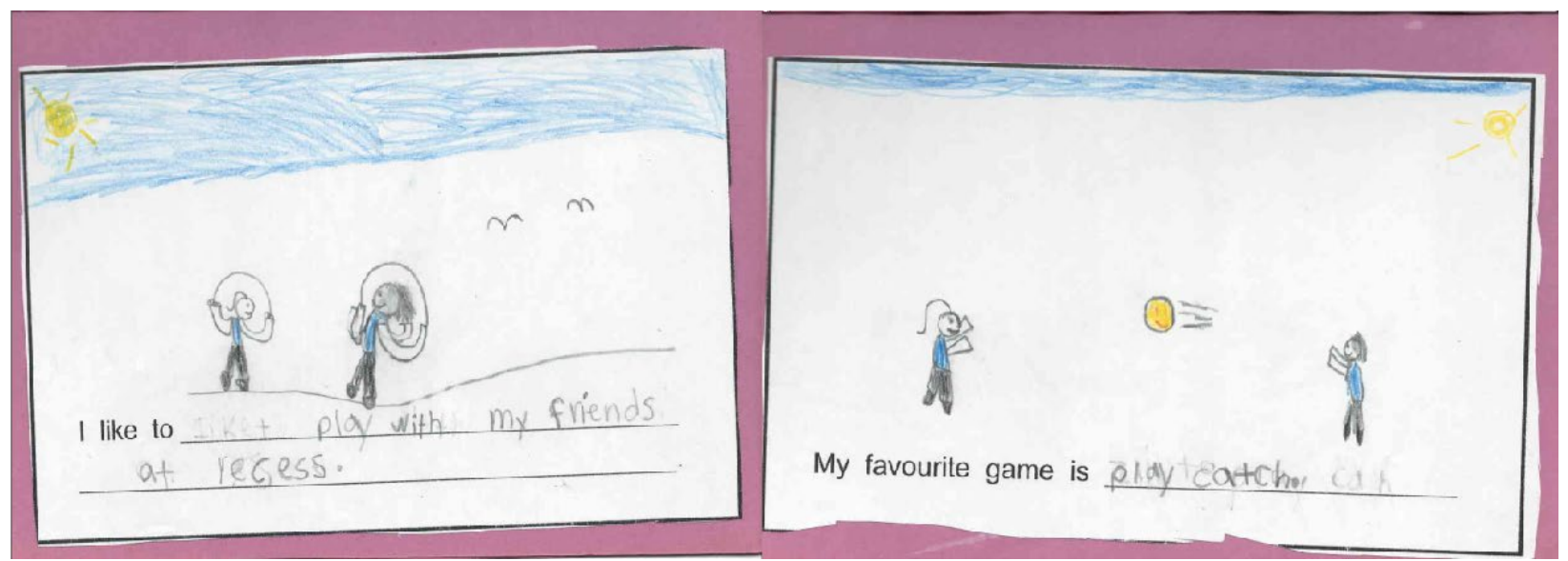

Play Catch

\section{Place \& Identity}

Berberich et al. (2012) explore the connections between land and identity, arguing that it is important to understand how we feel about and identify ourselves within places and how we react to the connections of others to place. Here, there is no restriction on the size of a place; it is simply a location that we attach meanings to (Cresswell, 2008). Relationships with one's homeland, where they were born, can be connected to identity in ways such as stories, language, music, and land (Berberich et al, 2012). When a person leaves their homeland, it can become difficult for them to maintain these identifying connections in a place where society values the dominant culture over all others (Sanagavarapu, 2010; Souto-Manning, 2007). The connections to place and sense of belonging that are built with and in one's homeland can be described as 
having a sense of place or placeness and this can foster one's feelings of belonging (Arefi, 1999). On the other hand, when these connections are not made or maintained, for example, in the case of immigrants who have limited or no connections at all to the dominant culture of their new home, their subsequent feelings of disconnect and lack of belonging can be defined as a sense of placelessness (Arefi, 1999). It is this repeated associations with place that inform identity formation based on the constructed meanings of individuals who interact with them (Arefi, 1999).

Marcouyeux and Fleury-Bahi (2011) conducted an empirical study on the concept of place-identity within schools. They noted that place-identity is informed by the ways that we learn within our environments. Places were attributed with the ability to hold and represent meaning for children, influencing how they identify themselves within them. This identification that emerges from the interacting perceptions of place and the development of place-identity within schools has the ability to affect a child's sense of belonging and self-esteem. Due to the large amount of time that children spend in schools, their school environment becomes a place that informs the construction of children's place-identity (Marcouyeux \& Fleury-Bahi, 2011). It is important for immigrant families to develop a sense of place in their new homes because it contributes to their identity and give them a sense of belonging (Convery et al., 2012). Having a sense of belonging is important for immigrant families and their children because it can help them to feel both valued and connected to place (Convery et al., 2012; Ontario Ministry of Education, 2014).

\section{Schools \& Educators}

Schools are places that many immigrant families have to navigate in their new homes. Classroom environments can be difficult to negotiate because they may value the dominant 
culture and undervalue minority cultures, making educational settings a site where renaming practices frequently occur (Kohli \& Solórzano, 2012; Nic Craith, 2012; Souto-Manning, 2007) (Schools spent weeks celebrating holidays like Christmas. They would give us crafts, read themed books, and throw class parties. On Diwali I received a colouring sheet of an oil lamp). It follows that there are often be negative impacts on the mental health of children who are being renamed (Nic Craith, 2012; Srinivasan, 2019). One example of this is in the experience of two sisters who experienced a sense of loss for their language and identity after being renamed by educators as a way to assimilate them into the dominant culture of their new home (Nic Craith, 2012). Similarly, and detailed by Kohli and Solórzano (2012) is the challenging experience of a renamed student who tried to reclaim their given name. This student was renamed by an educator who did not know how to pronounce his name, Nitin, and replaced it with Frank. Nitin described how he had to adopt the name Frank at school and how he continues to use it today as an adult, to the point where he would use it when interacting with people from his own culture (Kohli \& Solórzano, 2012). Nic Craith (2012) identifies these types of renaming practices as something that "silences a part of the individual and [in which] a loss has occurred that can never be repaired" (p. 117).

This quote scares me because as an adult I have been trying to in a sense repair the relationship I have with my name. I thought that by using it I was taking back my name. Now I am not sure this is possible. Have I started too late?

Listening for my name on the attendance on the first day of school always gave me anxiety. I knew I would be somewhere in the middle of the list because my last name starts with an M. On the first day of 
class, children are always looking around during attendance to match names to faces, trying to get to know their classmates. I was always worried about how the teacher would pronounce my name. They always pronounced my name as Mandeep. This wasn't unusual. (In fact, I think that I would find it weird to hear my name pronounced as मठटीय). Whenever there was South Asian substitute teacher they would pronounce my name as मठटीय. I felt embarrassed when my classmates would hear it. Some of them would try to imitate the pronunciation, exaggerating the accent, mocking the language. I would always feel that if I used मठटीय it would be associated only with South Asian cultures and stereotypes when I was trying so hard to represent myself as a Canadian.

Although educators were not a part of my peer or friendship groups, their presence in the classroom and their use of my name(s) played an important role in how other children subsequently used my name(s). The role of my educators in renaming me was important because of the inherent power that they held in the classroom (Kohli \& Solórzano, 2012). It is usually very early in the lives of children with ethnic names that they are pressured to adopt a name more reflective of the dominant cultures of their surrounding environments and this frequently takes place in early educational settings including child care centres and elementary schools (Kohli \& Solórzano, 2012; Souto-Manning, 2007) Immigrant families and their children can face immense pressures to conform and assimilate to their new homes while at the same time maintaining the cultures of their homeland (Penessi, 2016; Sanagavarapu, 2010; Souto-Manning 2007). For children, these pressures to change can come from schools because of their curricular reflection 
of largely western values (Kohli \& Solórzano, 2012). Due to the biases embedded in western educational systems, many researchers invited educators to reflect on the power that they hold over students of colour, calling for the curricular and pedagogical embrace of culturally responsive practices that do not further marginalize children (Kohli \& Solórzano, 2012; Peterson et al., 2015; Souto-Manning, 2007). It is important to correctly and respectfully use children's ethnic names, making sure to support and honour the connections that children have with their names, identity, and sense of belonging (Kohli \& Solórzano, 2012; Peterson et al., 2015; SoutoManning, 2007).

In school, I didn't feel like I had a choice about my name. It was whatever the teacher read it as on the attendance and it felt like that reading, correct or not, was set in stone. I would sometimes hear teachers ask if they pronounced someone's name correctly. I don't think I was ever asked that. I would always think about going down to the office and changing my preferred name to Mandy. I never did it though because I thought it would be weird to change it when everyone I knew in the school already knew me as Mandeep. I wasn't sure how I would make that change. How would I tell my parents?

There were often times and places where I could not change my name and this made it more difficult for me to blend in. Schools were one of the hardest places to hide my culture, especially since I went by the name Mandeep. Although my name was given an anglicized 
pronunciation, it was fairly easy to see how it was connected to my culture, language, and family (Peterson et al., 2015). As a child, I never corrected my teachers on the pronunciation of my name. They were in a place of power, authority figures who I did not feel that I was allowed correct (Kohli \& Solórzano, 2012). The anxiety I felt during attendance at school was dynamic and responsive as it changed from at first being worried that an educator would not pronounce my name correctly to later worrying that they would pronounce it correctly. At school, I was renamed so often as Mandeep that hearing my actual name became humiliating because of namebased bullying by my peers (Peterson et al., 2015).

\section{Name-Based Bullying}

When my name is pronounced as Mandeep, it just sounds like the words man and deep put together. Other children had pointed this out to me. Their bullying told me that my name didn't match my gender.

"I thought that Mandeep was a guy's name?" "You're a man and you're deep."

Sometimes they included my last name, Mann, "You have 'man' in your name twice." English letters aren't enough to convey the sounds and meanings in my name. My name gets lost in translation. 
This memory made me curious about the use of letters and characters outside the English language in official documents. I looked at Canadas' name change forms (something that I had once considered filling out) and newborn registration services but didn't find anything specific on the use of non-English characters but did see that they had guides on how to use letters with accents. This made me curious about the use of names in documents in other countries. I rummaged through my mother's closet and found my parents' old passports from before they had immigrated. Their names were written in English. Their parents' names were written in English. I wonder if the translation of their names was done at birth or was it something that came after. It made me think about Souto-Manning (2007), who wrote about the great value that is placed on the English language. It seems as if there may be almost no place that is untouched by the influence of western cultures.

Although students made fun of Mandeep as well, when they made fun of भठटीय, it felt worse because they mocked the language and made racist jokes (Peterson et al, 2005). Hearing educators pronounce my name as मठटीय exposes me as different, reaffirming perceptions that I am an outsider in a system that exclusively places value on the dominant culture above all others (Ashcroft \& Ahluwalia, 2001; Said, 1978; Sanagavarapu, 2010). Outside of school, Mandeep became a name that I was no longer comfortable using. For work and in other interactions outside of school when I no longer had to go by Mandeep, I began to go by Mandy.

When I tried to teach someone my name, I had to extract sounds and syllables for them from English words. The closest sounds I could think of were to take mon from money, add thee just like from the Canadian national anthem, and add a $p$ at the end. My last name I would 
describe as taking mon from Pokémon. (I used Pokémon because it was a popular show at the time and something I enjoyed. If you're reading this at a time that Pokémon is now somehow unknown or irrelevant, another example I could use is mon from monster).

This often didn't work out as well as I thought it would. My name sounded butchered and people often didn't try long enough to get it right, just long enough to laugh at it.

I think that the most common reason for my trying to teach someone how to pronounce my name was when "Mandeep" was made fun of. It was only an attempt to stop the teasing and try to discredit their claims about my name.

Although I could not hide my ethnic identity at school, I was able to do so with my online friends. Online, I could be whoever I wanted to be. A study by Kendall (1998) found that online spaces allow for interactions in which gender, class, and race can all be performed differently than they would be offline and in person. I could make invisible those aspects of my ethnic identity that could be discriminated.

In the summer of 2005, I started playing an online multiplayer game. I started grade 6 in September and was bullied by most of the girls that year. They would exclude me from everything. There were very few people I felt comfortable talking to at school, but even then it wasn't ever a place I was happy to be in. I started faking stomach aches and headaches so that I could stay home. During my fake sick 
days, I would just spend my day playing that online game; I had almost 60 sick days listed on my report card. But during that time I made some online friends and started spending even more time online. I felt that I could truly be myself with them...sort of. I would never tell them I was Indian. When I would meet someone in the game, I would introduce myself as Melissa, a white girl from Canada. My thinking was

that if I said I was Indian and I told them my name, there was a chance that they would make fun of me. I didn't want to take that risk. I didn't want to lose any more friends. I was afraid to tell them the truth. I thought that they would stereotype me if they found out who I really was. I had to lie to the only real friends I had.

There are many different definitions and forms of bullying. The Public Health Agency of Canada (2016) recognizes bullying to be the "wilful, repeated aggressive behaviour with negative intent used by a child to maintain power over another child" (para. 1) and identifies aspects of bullying to include unequal power, hurtful actions, direct or indirect actions, and repetitive behaviour. In 2012, 47\% of Canadian parents reported that their child was a victim of bullying (Canadian Institutes of Health Research, 2012). A study by Bajaj et al. (2016) highlighted connections between racism, xenophobia, and bullying after the events of 9/11, focusing on youths from various communities, such as South Asia and North Africa, who had been labeled as foreign threats in the United States. Rampant Islamophobia contributed to an increase in bullying and violence directed at youths who are perceived to be Muslim (Bajaj et al., 2016). Similar to the United States, Canada had also reported an increase in hate crimes towards 
communities and people who were perceived to be Muslim (Khalema et al., 2003). These racially motivated crimes ranged from verbal harassment, physical assault, and even murder. Khalema et al. (2003) found that those typically and correctly or incorrectly assumed to be Muslim actively hid visible markers of their religious background and changed their names to avoid discrimination. Although Bajaj et al. (2016) highlights links between bullying and racism, a study by Priest et al., (2016) found that bullying victimization and racial discrimination as childhood stressors should not be lumped together because their long term effects are unique. One potential reason for describing acts of racism committed by children as bullying could be that parents and educators often do not talk to young children about race because they are facing pressures to follow colour blind norms that deter discussions on race (Pauker, 2016). In some cases early childhood educators believe that children should not be talked to about race until later in their elementary school years (Husband, 2010). These educators have these beliefs even though some children in the United States have demonstrated awareness of racial differences and displayed discriminatory behaviours towards some racial groups at the age of three (Beneke \& Cheatham, 2019). (I'm curious as to how many acts of racism are brushed off as bullying or teasing...) These colour blind approaches to race and racism only help these issues remain hidden because if they are not acknowledged they cannot be fixed (Husband, 2011).

I was pretty young during the events of 9/11. I was in grade two. I remember coming home and standing in front of the television in my living room, watching replays of the attacks. I do not remember much more from that time and the types of bullying that I endured or observed. I do however remember years later (perhaps grade 5 or 6) how often the word "terrorist" would be used against Brown people. I remember hearing about incidents where 
people with visible religious markers were purposefully targeted and attacked (one even happened at school).

My online friends and I had shared our emails and we would talk every day. My name wasn't on my email so it was easy to keep up my false identity. One day I woke up to a Facebook friend request from one of my online friends. They found me through my email. My heart sank into my stomach. My Facebook had my real first name. They would know that I was lying. I quickly deactivated my Facebook account as if it would somehow erase what they saw. I reluctantly logged on to the game and saw that my friend who added me was online. They asked me why I was lying when I was really just some Brown girl. I closed the game before they could say anything else and didn't log on for days after. I ended up making a new account with a different name. I didn't want to face them again, not after I lied to them for so long.

I was not careful enough with my online identity and my name and ethnic identity were revealed. I had internalized racism to the point where I would represent myself as white when I had the option to. My experiences with stereotyping and bullying taught me that people with my ethnic background are viewed in a certain way and this forever marks me as a foreigner. The numerous friendships that I had made in this online community instantly disappeared. It is possible that my online friends may have been upset simply because I lied about my name and ethnic identity, but to be called just some Brown girl marked me as foreign and unwanted. 


\section{Family}

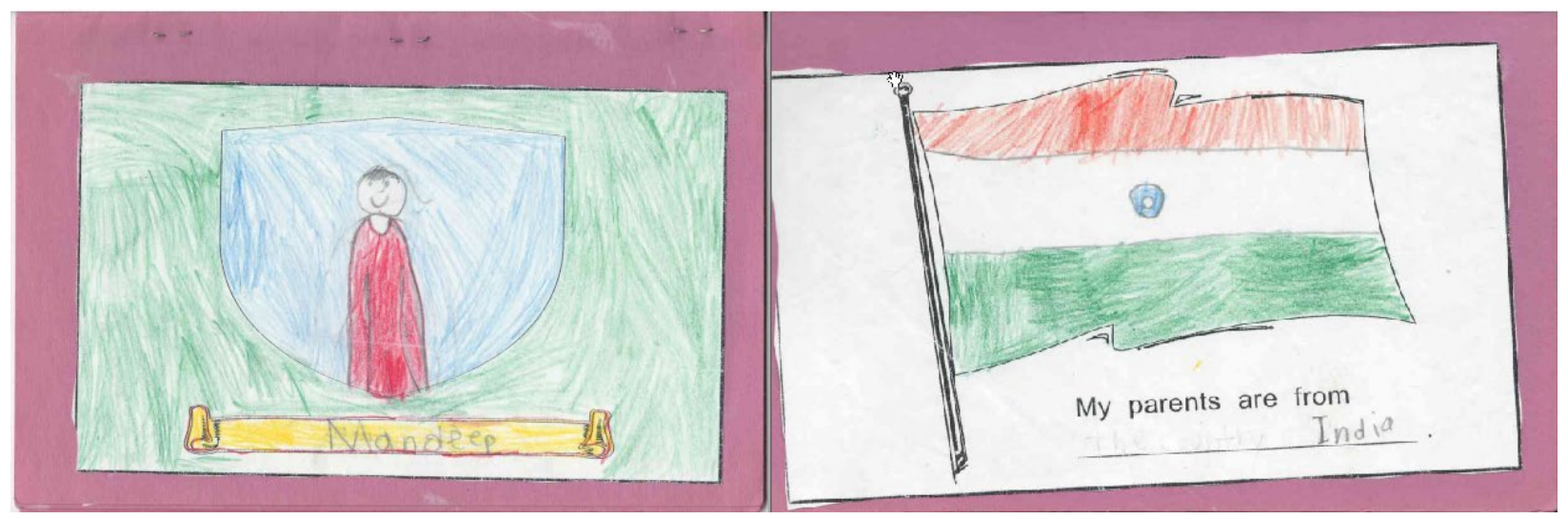

Where Are You From?

\section{Where Did My Name Come From?}

My mother asked me if I wanted to change my name. She called it old fashioned. She said that she was initially going to name me Jessica, but named me भठटीय. I was already in middle school so I felt that I was too old to be changing my name. I knew that when she said my name was old fashioned, what she really meant was that she realized my name didn't fit in with the names of other Canadian children. She must have noticed that a lot of South Asian kids at school had ethnic names that were a lot easier to pronounce than भठटीय or Mandeep such as Nisha, Priya, and Alisha. At least, I noticed. I told her it was fine, that I liked my name.

I hated my name. 
There have been cases where immigrant families have chosen names for their children while taking consideration of their name-based experiences growing up (Pennesi, 2016). My name looks fairly simple to pronounce (If you're using an anglicized pronunciation) but I do not believe my mother thought too much about how it would impact my future in Canada. She may have simply thought about it in terms of what it meant to her (and perhaps her wishes for what it was to mean to me). My name has ties not only to South Asia and Punjab but also to the Sikh religion. Some Sikh families name their children using a naming ceremony called Nam Karan (Gatrad et al., 2005). This ceremony can take place at a Sikh place of worship called a Gurdwara (house of the guru) or at home (Bains, 2020; Jakobsh, 2012). During the ceremony, the Sikh holy book, the Guru Granth Sahib, is opened to a random page where the first letter on the left page is used to choose a child's name (Gatrad, et al, 2005; Jakobsh, 2012). Not all families choose to name their children through Nam Karan. Some families, instead, consult with other family members (Gatrad, et al, 2005). However, all of these names all have religious meanings; for example, मठटीय (Mandeep) means "light of sages" (Gatrad et al., 2005). Names are usually linked to gender but Sikh names are often unisex (Gatrad et al., 2005; Peterson, et al., 2015). Sikh naming practices often also add Singh (meaning "lion") for boys and Kaur (meaning "princess") for girls in place of their surnames as a rejection of the caste system though many Sikhs instead adopt them as middle names (Gatrad et al., 2005).

My name was not chosen using Nam Karan, but rather through consultations with family members. Although my name is legally written as Mandeep, its translation to the English language makes it difficult to pronounce based on the spelling. Pennesi (2016) argues that the burden of integration can push immigrants to choose English names or a version of their name that sounds "Canadianised". Li (2003) has highlighted major differences in how the Canadian 
government has viewed who the burden of integration is placed on. He found that Employment and Immigration Canada (1993) insisted that the dominant culture should be accepting of the differences of newcomers but at the same time maintained that immigrants should adhere to Canadian values and standards to be socially and economically successful. These contradictions have changed in more recent policies that have seen the integration process as a two-way street, but the general ideas surrounding integration place burdens and expectations on to immigrants (Li, 2003). There are 35 core letters in the Gurmukhi (Punjabi) alphabet as well as 16 other variations of some of them to create additional consonants and vowels (Deep \& Goyal, 2011). With differences in language it can be incredibly difficult to accurately phonetically translate मठरीय into the English alphabets 26 letters. The meaning of my name also changes in the English language. Someone with no knowledge of the Punjabi language would likely not know the meanings behind my name. The burden is then placed on me to educate others who would mispronounce or misinterpret the meanings of my name.

I have joked around before about people referring to me as Light of Sages. If I translate my full name through meanings instead of phonetically, my name would be Light of Sages Princess Mann (Unfortunately I have no idea what Mann means in Punjabi). What a mouthful. Although, not even this translation fully captures the significance and meanings of these names.

I have been asked a few times about my last name because of its similarity to a name with German origins. It made me think that I had some German ancestor and maybe that I wasn't only Indian. Maybe I was also white? This was information that I began sharing with people who 
asked me where I was from. It was something I was proud of. I later learned that my last name isn't really Mann. It was just translated like that. In Punjabi it’s probably closer to Mainn or Māna.

The meanings that people have applied to my last name vary. When I first heard that Mann was also identified as a German last name, I was surprised. How could I have a German last name? I had heard nothing about this from my family. When I had consulted them about a possible connection to Germany and Europe, they gave me some stories about family who may have visited Germany. Just visited. But, this was enough information for me to start believing that there was some possibility that I had German ancestry. I held on to this idea that I was not just some Brown girl, but someone who could make legitimate claims to whiteness. I happily volunteered this information any time I was asked about my name or ethnicity. I made claims to whiteness to distance myself from the meanings associated with South Asian cultures and to feel a sense of belonging.

\section{Losing My Language}

My father speaks to my siblings and me in Punjabi, but we would always reply in English. My mother would ask us to speak only Punjabi for a full hour in the evenings before bed but we often made excuses to not participate. She said that we would forget our language and wouldn't

be able to teach it to our own children. She was right. My Punjabi isn't as good as it used to be. I can only hold short conversations now. I'm not put in many situations in Canada where I would need to 
speak Punjabi other than with my grandparents. I don't use Punjabi as much now because I am embarrassed at how much of the language I have forgotten, and I am forgetting, the language because I don't speak it.

Immigrant families living in western countries are often forced to assimilate, negotiating which aspects of their culture to keep and which aspects of the dominant culture to adopt (Sanagavarapu, 2010). Ideas surrounding assimilation of immigrants often place their culture in an inferior position to the culture of the dominant group (Souto-Manning, 2007). I had placed many aspects of my culture as subordinate to Canadian culture. One of the consequences of this was me losing quite a bit of my linguistic heritage. Language is one of the most significant barriers that immigrants face when moving to a new place (Nic Craith, 2012; Souto-Manning, 2007). Souto-Manning (2007) highlights the high value that is placed on learning English, noting that there are still stereotypes claiming a negative correlation between bilingualism and intelligence. In other words, stereotypes persist that perceive those whose first language is not English to be less intelligent. For example, children from the growing Latino population in the United States are often viewed through a deficit lens in early education settings because of their language. The experiences of Latino students are only symptoms of a much larger issue that their entire families and communities are facing. Souto-Manning (2007) asserts that we must challenge this cultural identification that values only the English language and instead value other languages as assets and strengths rather than shortcomings.

My father immigrated to Canada when he was around twelve years old and has retained his Punjabi language skills as well as gaining fluency in English. It is always interesting to hear him switch between languages; he does not even sound like the same person. Although my father 
always spoke Punjabi to my siblings and me, we slowly stopped replying in Punjabi and began to instead use English. My parents never forced us to speak Punjabi. They felt it was important for us to learn English in school. I did, however, continue to speak Punjabi with my grandparents. In the Punjabi community, grandparents are often very involved in the upbringing of their grandchildren (Smythe \& Toohey, 2009). I maintained many of my Punjabi language skills through my interactions and conversations with my grandparents. These dialogues are one of the only remaining ways that I retain my linguistic ties to my culture. Another factor that weakened my linguistic ties was my siblings. We spoke English with each other because it had become our most fluent language (Was it really my siblings then? Or was it because of how Canadian culture affected them?).

My fluency in Punjabi allowed me to connect with people around the world. It allowed me to participate in the community and maintain my cultural ties through music, stories, film, and folk tales. As I conversed in Punjabi less frequently, I started to lose the ability to communicate with my friends and family. A language I once thought of as an asset only on my resumé is now something I now try to hold on to tightly. I cannot risk losing any more of my language and in turn my cultural identity. 


\section{Self}

Canadians have a favourite pastime, and they don't even realize it. They like to ask - they absolutely have to ask - where you are from if you don't look convincingly white. They want to know it, need to know it, simply must have that information. They just can't relax until they have pin-pointed, to their satisfaction, your geographic and racial coordinated. They can go almost out of their minds with curiosity, as when driven by the need for food, water, or sex, but once they've finally managed to find out precisely where you were born, who your parents were, and what your racial make-up is, then, man, do they feel better. They can breathe easy and get back to the business of living.

- Lawrence Hill, Black Berry, Sweet Juice

\section{Naming and Identity}

I have so many names and so many ways that I use them. The one name that I hear the least is भठटीय. I can't remember the last time I have heard it. I am supposed to identify with my name and have strong connections to it, but I don't feel that way. Nobody was there to reinforce my connections to my name. At home, they just call me भீळ్. How can I build a connection with a name that I don't hear or say? I feel an unexplainable sadness when I think about my name. It feels like I’ve lost something. Why did nobody use it? Why didn't I use it? 
Names can be linked to various meanings such and language and ethnicity that in turn inform the social identity of an individual (Pennesi, 2016). They allow us to identify ourselves as individuals when we use them to introduce ourselves to others. The process of identifying with one's name begins in the early years of life. For example, when a baby's name is regularly used to identify them, this reinforces the baby's own recognition of and identification with their name (Kohli \& Solórzano, 2012). These early interactions are also a way for children to learn the pronunciation of their names and make connections between this pronunciation and their developing identity (Kohli \& Solórzano, 2012). If naming had the ability to create and construct identity, then renaming practices can be seen as a way to dismantle and remove or alter identity (Jagieła \& Gębuś, 2015).

\section{Identity Theory}

From the sociological perspective of identity theory, identity has been defined as a dynamic combination of characteristics that define us as unique individuals (Burke \& Stets, 2009). Identity theory draws from symbolic interactionism, which is a perspective that understands human behaviours through shared cultural meanings drawn from symbols (Blumer, 2005; Burke \& Stets, 2009). An individual can have many identities with their own sets of socially defined meanings (Burke \& Stets, 2009). These identities can overlap and at times be in conflict with each other. This theory has examined identity through role identity, social identity, and person identity (Burke \& Stets, 2009). 
Role identity has been defined as "the internalized meanings of a role that individuals apply to themselves" (Burke \& Stets, 2009, p. 114). It considers how an individual can possess multiple roles depending on their various social structural positions within society (Burke \& Stets, 2009; Stets \& Burke, 2014). These roles can have shared external social meanings as well as internalized meanings that can influence our expectations and interactions with others (Burke \& Stets, 2009). Some examples of these positions can include being a neighbour, a parent, a manager, and a friend. Here the identity of individuals is evaluated based on what they do (Burke \& Stets, 2009).

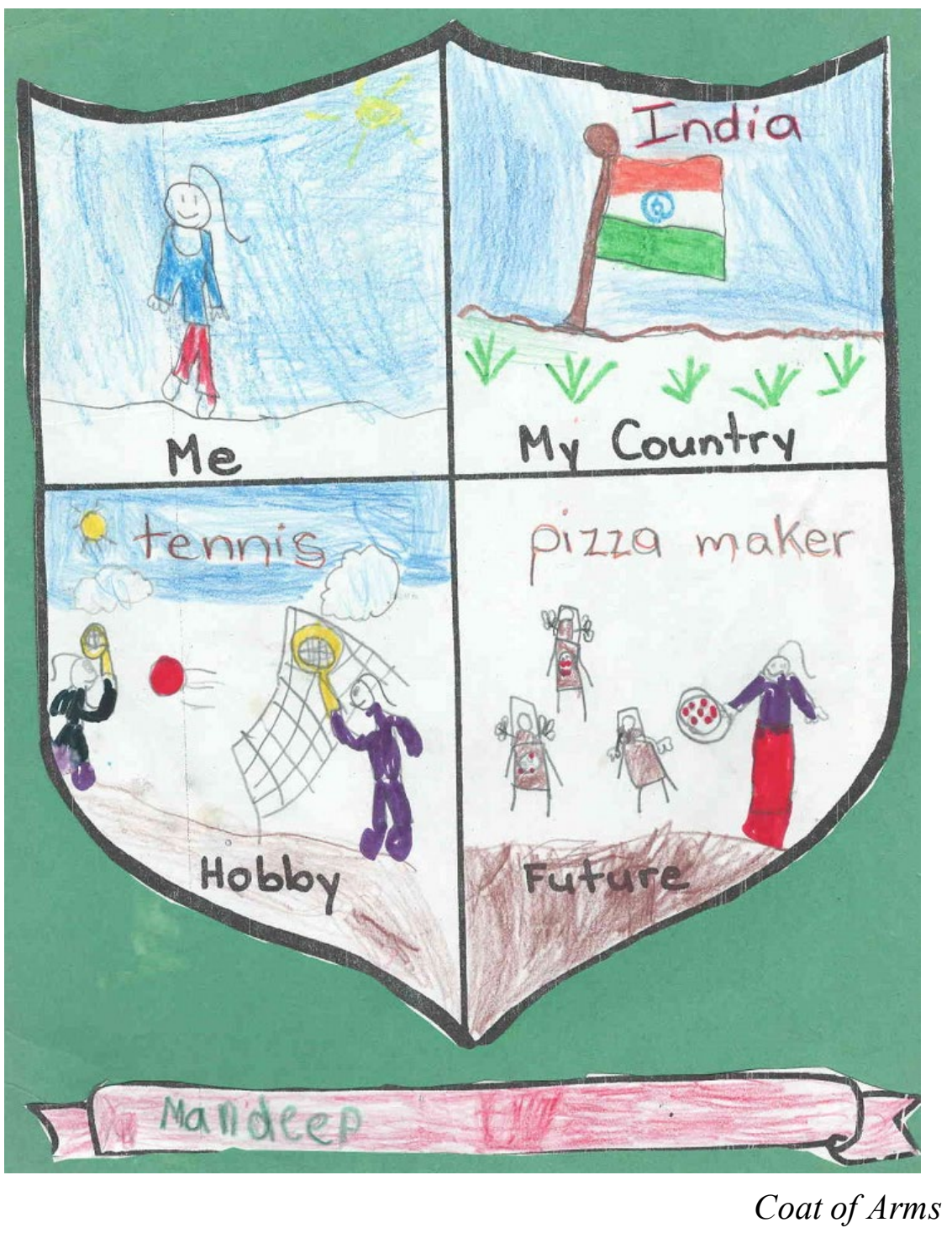


Worksheets and art projects early in the year in primary school often involved questions of who we are and where we are from. I was always hesitant to put down an answer. What would I draw? An Indian flag or a Canadian Flag? If someone asked me this question I would usually say "My parents are from India but I was born in Canada." How am I supposed to reflect this in a drawing? I would look over at work of other South Asian children to see what they were drawing. Something about drawing a Canadian flag didn't feel right. It didn't feel like the worksheet was asking me where I was born, where I lived, or where I was a citizen. It was asking my ethnicity. From what I can remember, my choice was always the same. An Indian flag. So why was I so uncertain every time I was asked?

Like role identity, different social and person identities follow standards that direct their behaviour and are negotiated based on an individual's interactions (Burke \& Stets, 2009). Social identity is an individual's membership to different social groups including religions, sports teams, and social class. These groupings are created by the categorization of ourselves and others through our commonalities. This classification establishes an ingroup that recognizes anyone fit with those categorizations as being in an outgroup. This binary segregation creates positive perceptions of people who are a part of our ingroups and negative perceptions of people who are members of outgroups (Burke \& Stets, 2009). When an individual feels accepted as part of an ingroup, this membership can strengthen their sense of belonging and heighten their self-esteem 
(Caste \& Burke, 2002; Stets \& Burke, 2009). Here the identity of individuals is evaluated based on who they are in contrast to what they do in their role identity (Burke \& Stets, 2009).

"Where are you from?" This question is often not posed to find out where someone is from. Today, I would answer this question as if it was literally asking me where I was from. I am from Canada. Somehow this is interpreted as the wrong answer; it is not the answer they were looking for. It's often followed up with, "No, like, where are your parents from?" As a child, I felt that I could not give Canada as an answer without justifying why, especially since I was asked this at school where people knew me as Mandeep. It is a name that is both ethnic and anglicized, revealing my dual South Asian and Canadian identities. My ethnic identity as a South Asian was in direct conflict with my social identity as a Canadian (Burke \& Stets, 2009) with both identities trying to maintain their unique meanings but clashing. This conflict can lead to changes and adjustments to the identities involved in the conflict so that one can become more salient than the other (Burke \& Stets, 2009). This identity conflict challenges perceptions of the self and can lead to negative emotions when an identity is not verified (Burke \& Stets, 2009; Stets \& Burke, 2014).

I don't think anybody knows me as भठटीय. That person does not exist to anyone outside of myself. My names almost feel like labels for fluid and intersecting personas. When I use मठटीय it almost feels like an act. I try to challenge myself to use मठटीय consistently, even when it is not advantageous to my situation. Why should I hide my name? And why does the burden fall on me to make it easier for someone else to 
negotiate? Why do I have to conform? I should not feel embarrassed when others fail to pronounce my name correctly. I shouldn't be so quick to give them an out, to give them an excuse to not learn my name. I should let them sit with that uncomfortableness, just as I

have.

Person identity is a combination of the internalized meanings or characteristics, separate from their role and social identities, that an individual identifies with that differentiate them from others (Burke \& Stets, 2009). Examples of person identity include being trustworthy, being mature, and being rational. The meanings of these characteristics are drawn from shared cultural understandings of them; others will attribute the same meanings to those characteristics. Person identities can act as a basis for how an individual understands themselves and these understandings can subsequently inform their role and social identities. In cases where a person has limited control over their choices, it is also possible for role and social identities to influence person identity (Burke \& Stets, 2009).

My names themselves have acted as labels for different role and social identities. Many of these identities overlapped and therefore so did their expected behaviours (Burke \& Stets, 2009). My identities were chosen and negotiated through my engagements with the people and places I was interacting with (Stets \& Burke, 2014).

\footnotetext{
Nobody ever said to me that my name didn't matter, but it definitely felt like that was the case. Does it matter to me now? I kind of feel
} 
that it does even though I don't always use it. It's been hard deciding when and where I should present myself as more Indian or more Canadian. I don't always get it right and it makes me feel like a hypocrite. I can't please everyone. Why can't I just be me?

What does it even mean to get my name right? I'm not changing it for me...I'm changing it for others. It only works for me if it works for others.

Stryker and Burke (2000) use the term identity salience to refer to the likelihood that one identity will be more prominent than others. The salience of each individual identity is dependent on the circumstances of each situation, although, there are some identities that are likely to be more dominant across multiple situations (Stets \& Burke, 2014). The order of identity salience within each individual has been described as a salience hierarchy (Stryker \& Burke, 2000). Each identity also has different guidelines that regulate the types of behaviours that convey messages appropriate for that identity (Stets \& Burke, 2000; Stets \& Burke, 2014). This means that the more salient an identity is in the hierarchy, the more likely we are to act in accordance with the behaviours associated with it (Stryker \& Burke, 2000). Although we have some more salient identities, our interactions with others can make us negotiate our identities based on our perceptions of the identities of each other (Stets \& Burke, 2014).

With the use of each name, my identities shifted in the salience hierarchy so that my behaviours were in line with the image that each name was intended to reflect (Burke \& Stets, 2009). Across all of my names, there was always conflict between my South Asian and Canadian 
identities. These social identities as well as my role identities were shaped by my person identity and vice versa (Burke \& Stets, 2009). This constant switching of names and associated identities was challenging. There were times where some aspects of my identity became more salient than others while I was using a name that conflicted with those aspects of my identity. For example, when I would try to teach classmates my name, I pronounced it using a Punjabi accent associated with my South Asian social identity. In this context, I typically took on the role identity of a student, a peer, and a friend. These roles normally did not have such salient interactions with my South Asian social identity. The interaction between my identities related to the name Mandeep and my social (as well as ethnic and racial) identity may have been interpreted as unusual to my friends and peers because it was usually my Canadian social identity that was more salient and familiar. My behaviours associated with my South Asian identity placed me in an outgroup which leads to the laughter of my peers (Burke \& Stets, 2009). Their laughter could be interpreted as a non-verification of my person, role, and social identities which altered the meanings I attributed to them (Cast \& Burke, 2002). These challenges to the self-verification process have been known to be detrimental to emotional health, with consequences such as depression and anxiety (Cast \& Burke, 2002). I did not have much control over removing myself from these situations because they would often happen in school. The most I could do to extricate myself was to fake being ill, but that could only work so often. Thus, I tried to disassociate and distance myself from my South Asian identity. It became the identity that was the least salient for me in schools because of all of the negative feelings associated with its nonverification (Cast \& Burke, 2002).

\section{Racial \& Ethnic Identity}


Another way of conceptualizing identity is through racial and ethnic identity. Although the terms race and ethnicity are often overlapping and are used interchangeably, it is important to understand their differences (Lee \& Ahn, 2013). Race refers to the construct of groups used to define people who share different biological traits such as skin colour (Delgado \& Stefancic, 2017). Racial identity has been conceptualized as identifying "with groups of people who have been socialized as belonging to a racial group (Helms, 1993, as cited by Lee \& Ahn, 2013, p. 1). On the other hand, ethnicity refers to groups of people who share "national origin, ancestry, language, or other cultural characteristic or pattern" (Delgado \& Stefancic, 2017, p. 174). Ethnic identity refers to identifying with others who share the same ethnic group (Lee \& Ahn, 2013). Some meanings attributed to racial and ethnic identities extend from the processes of racial and ethnic socialization (Berkel et al., 2009; Mohanty, 2013). Racial and ethnic socialization both refer to the processes at work when adults provide their children with information on their race and ethnicity (Hughes et al., 2006; Mohanty, 2013). Racial socialization occurs when parents educate their children about valuing race as well as the barriers they will face because of their race (Berkel et al., 2008; Hughes et al., 2006). Ethnic socialization is a practice where parents teach their children about different aspects of their ethnicity (Dimitrova et al, 2018; Hughes et al., 2006).

Interactions such as these caused my Canadian social identity to take a higher place in my identity salience hierarchy, eventually impacting my person identity (Burke \& Stets, 2009). These influences guided how I saw myself and how I represented and presented myself to others across multiple roles (Burke \& Stets, 2009). In my childhood and youth, it was very difficult to try to find a balance between my competing social identities, and it remains challenging today. I face pressures from both sides, from western cultures and South Asian cultures, with the former 
telling me to conform to the dominant culture and the latter urging me to maintain my South Asian culture (Sanagavarapu, 2010). My childhood experiences led me to create and accept names that divided and subdivided my identity into so many versions of myself that govern how much of my ethnic and racial identity I feel comfortable revealing. In these 25 years of my life, I have just been adding to the list of names. I wonder if I will ever remove one or if I will simply continue to name and rename myself? 


\section{In Retrospect}

I picked up my phone and noticed I had a new voicemail. I just received the feature with my new phone plan. I called it and was required to set up a greeting before I could listen to the message. "At the tone, please state your name" I paused for a few seconds and hung up. I had no idea what to say. My mind blanked.

I thought for a moment and called back. "At the tone, please state your name" "भठरीय"

I played back the greeting and I deleted it. It sounded weird so I tried again. "At the tone, please state your name"

"भतरीय"

It still sounded unusual to me, but less so.

I kept it.

This experience took place in July 2020 and I was 25 years old. I was pushed to pick a name that could be heard by anyone who had my contact information. Most people who have my contact information know my legal name (Mandeep) even if some of them may call me Mandy. Using भठटीय here made sense to me. It's not too far of a leap from Mandeep. 
Nobody uses मठसीय but I feel good about having it there. My confidence in using my name has grown but I do slip back into using other names occasionally.

My relationship with my names remains complicated to this day (some days I think it has gotten worse). It has been challenging trying to move away from giving anglicized and altered names purposefully for the reason of hiding my ethnic identity. Through my narratives I have had opportunities (and the misfortune) to relive my childhood experiences. As a consequence of this I have been able to recognize renaming so much more consistently, not only of myself but of other people and places (How much of it has gone unnoticed by me? By you?).

As I write and read my narratives I struggle with the idea that my experiences may not be meaningful or impactful. Reading them individually casts a cloud of doubt. Was it my imagination? Was I reading the situation wrong? It is just a name, but it is my name. Reading them together allowed me to paint a bigger picture of my renaming and allowed me to uncover patterns and ideas I may not have realised otherwise. My experiences are real and they reflect the legitimate everyday racism I experienced and subsequently internalized. My names have played an important part in the construction of my identity throughout my interactions in my communities, family, friendships, and self. As I wrote this paper I imagined a world where I would not fear using my name, revealing myself as different. Reading the experiences of people (through research, literature, history, friends, and family) who have been renamed helped me identify multitudinous times I have been renamed and gain some understanding of why.

My inquiry of my renaming within my larger communities involved: 1) an exploration of factors that uphold white supremacy in a Canadian context; 2) a look into South Asian identifiers; 3) colonial representations of Eastern countries; and 4) renaming as a microaggression. This provided a background of the existing environments and structures that 
stimulated behaviours and ideas which reinforced renaming practices. A look into Andrea Smith's (2006) Three Pillars of White Supremacy framework aids us in dismantling white supremacy. Yee (2005) argues that dismantling the racist systems that continue to oppress BIPOC requires whiteness to be named and understood to remove it from the position of the "status quo." Pairing this with examples from Canada allows us to see how the three pillars interact in Canadian history, once again exposing white supremacy that has remained well hidden in our so called cultural mosaic (Hogarth \& Fletcher, 2018). Looking into the identities of South Asian, Desi, and Brown highlights inconsistencies and criticisms of racial and ethnic identifiers that have the ability to both homogenize and exclude people who originate from the Indian subcontinent. Understanding the inconsistent use of these identifiers in the South Asian diaspora interrogates how we use our racial ambiguity to negotiate our identities through social meanings of race (Harpalani, 2013). Pairing a discussion on orientalism and whiteness exposes how the west used knowledge and power to differentially racialize the East to maintain power over them (Iftikar \& Museus, 2018; Said, 1978). Identifying microaggressions and Canadian histories of renaming practices allows us to uncover forms of racism that may not always be as identified as racist (Delgado \& Stefancic, 2017). In the community layer, these pieces all interact with each other and with my narratives to uncover, expose, and name whiteness and white supremacy. Only by identifying these systems will we be able to legitimately fight them (Yee, 2005).

Within my friendships and peer groups my narratives led me to look into: 1) relationships with place; 2) schools and educators; and 3) name-based bullying. My narratives depicted the choices I made about which names to use depending on my surrounding environment. This made 
it important to understand how my identification within those environments was impacted by my connections to place.

It is truly fascinating how quickly I can switch over to another name. I could walk out of the back room at work and on to the sales floor, going from Mandeep to Mandy immediately. I could be waiting in line for food with my sister as $\mathcal{H} \widehat{\underline{D}}$ but the second the cashier asks for my name it becomes Mandy.

My narratives within schools focused on continuous renaming by educators. My name felt set in stone once it was read aloud by the educator (it was probably set in stone the first time an educator said it and just reinforced every school year, unchanged since kindergarten). I perceived my culture as being less valuable than others in school (unfortunately this was and is not limited to schools...). This may have contributed to my name-based bullying experiences in schools. Bullies used my anglicized name against me. They gave it meanings based on western ideas and their perceptions of my culture. These experiences altered my views of my anglicized name, pushing me to alter it instead to a name that would blend in better within the dominant culture in Canada (In person and online). In this layer of analysis, my narratives can be understood to convey my fears of being marked as foreign. Within these narratives I see myself as trying to maintain an image of myself as an insider to avoid discrimination.

Narratives involving my family compelled me to look into: 1) the origin of my name; and 2) my diminishing knowledge of the Punjabi language. Understanding how I was given my name and the meanings that South Asian names can hold is important for understanding the significance of my name. My racial ambiguity, use of the name Mandy, and the unclear origins of my last name became a near perfect medley of factors that hid my ethnic identity (and now with the use of masks during this pandemic you really can't tell...). The Punjabi language has 
direct ties to my name. It gives it its meaning and pronunciation. I have begun to use Punjabi less and less often, at the cost of decreasing my fluency of the language. This lack of fluency is very apparent to me when I find myself consciously trying to translate my sentences from English to Punjabi. It used to be so much easier than this.

Is it silly to think that I can completely forget how to say my own name?

My name and language keeps me connected to my family and South Asian communities. The value placed on learning the English language has pressured me to place my language and my name in a position of inferiority to the dominant culture (Souto-Manning, 2007).

An exploration of my connections to and use of names involved an investigation of: 1) naming and identity; 2) identity theory; and 3) racial and ethnic identity and socialization. It was important to link the use of naming to identity to understand how my identities shift with each renaming. It highlighted the important connections we have to our names and how renaming has the ability to remove or alter identity (Jagieła \& Gębuś, 2015; Kohli \& Solórzano, 2012). An analysis of my experiences through identity theory allowed an understanding of how ingroups and outgroups dictated the salience of identities in different situations (Burke \& Stets, 2009). It shows how my names became labels for my overlapping role and social identities and associated behaviours (Burke \& Stets, 2009). Racial and ethnic identity show how people are perceived by others and by themselves as belonging to specific groups (Delgado \& Stefancic, 2017; Lee \& Ahn, 2013). The socialization of these identities by parents to their children teaches us how children can learn about themselves and their communities early in their lives and the barriers they may face (Berkel et al., 2008; Hughes et al., 2006; Mohanty, 2013). Within this layer I have made sense of how I as an individual negotiate identities in multiple situations. 
Recovering old memories of my renaming forced me to confront why I was (and still am) fearful and hesitant to share my name. Histories of renaming practices in Canada highlight many instances of taking away identity. Through my narratives I have found that these acts have now become more subtle. While I cannot say for certain that historical renaming practices and current renaming practices have the same effect, I argue that they are still connected by the same values and ideas that uphold white supremacy. Through my experiences and literature I have highlighted the importance of correctly using children's (not even just children, but everyone's) names, making sure that we reinforce the connections that they make with their names, and in turn, their identity and sense of belonging (Kohli \& Solórzano, 2012; Peterson et al., 2015; Souto-Manning, 2007). My writing on my experiences touched briefly on my name and how it does not conform to western ideas of naming and gender. Although not explored specifically in my research, the analysis of gender and naming are significant in understanding renaming practices. Current research has shown that the process of assimilation for immigrants can be gendered (Sue \& Telles, 2007). Building on this, future research could explore how western ideas of naming and gender affects South Asian naming practices. This could be explored through immigrants who have been renamed as well as the names they have chosen for their children. It could also be interesting to see how naming practices change throughout generations within immigrant families.

Although I cannot speak for all people in South Asian and Desi communities I hope those who have been renamed can find representation within my inquiry so that they too can question why they have been renamed and how it has affected their lives. Although this research focuses on myself as a South Asian and a Canadian, I believe that the findings can be significant for anyone whose names do not fit into the dominant culture. We as educators, friends, and members 
of society who interact with people with ethnic names need to take a long hard look into why we engage in renaming practices and what it can mean for the people are being renamed by themselves and others because of the value we place on western culture and language (Peterson et al., 2015; Souto-Manning, 2007).

My mind wanders to the recent and tragic death of George Floyd as well as the movement it set off around the globe. It sparked protests highlighting injustices faced by Black communities. My social media was (and still is) flooded with posts calling for change. \#BlackLivesMatter \#JusticeForGeorgeFloyd \#BlackTransLivesMatter \#JusticeForBreonnaTaylor \#DefundThePolice \#SayTheirNames

Companies began putting out statements on how they were planning to fight against antiBlack racism. I saw a lot of criticism about their empty words, promises, and meaningless changes. These companies have made some small changes, but so what? That doesn't really solve racism now does it? I think about how the same thing could be said about renaming practices. Although small changes may seem insignificant to some, it is important to call out all forms of racism. The systems that uphold white supremacy thrive when invisible. It is our job to make it visible. Unmasking these injustices (no matter the size) and exposing them for what they are is part of the process of deconstructing whiteness and dismantling white supremacy (Yee, 2005). We can acknowledge these changes (even when they are performative) but it is also important to never stop fighting for more; to not lose sight of our goals. 


\section{Appendix A}

Recruitment Email

\section{Ryerson}

University

\section{South Asian Names, Identity, and Sense of Place (REB 2020-171)}

Hello (name of potential non-active participant),

My name is Mandeep Mann. I am a student at Ryerson University in the Early Childhood Studies MA program. I am contacting you to see if you might be interested in participating in a research study titled South Asian Names, Identity, and Sense of Place.

This research is being done as part of my Master's project and my supervisor's name is Dr. Susan Jagger. The focus of the research is to explore the experiences of children with 'ethnic' names who are experiencing their names being altered, changed, and/or mispronounced by themselves and/or others to assimilate them into the dominant culture. I will be exploring this through an autoethnographic study of my own experiences and related impacts. There will be a total of 7 non-active participants in this study.

If you agree to volunteer you will be asked to provide your ongoing consent to be a non-active participant in the study, meaning that you will not participate in data collection (i.e., you will not be interviewed, complete a survey, etc.). You will however participate through your inclusion in my reflective research writing (e.g., you will be included in my writing about experiences that you were present for). You will also be asked to provide demographic information on your ethnicity and gender. You will be asked to reaffirm consent after initially reviewing research writing samples and after reviewing any major changes in how you are being featured in the research. You will also be asked to reaffirm consent once a final draft is completed and before the research project is disseminated.

Your participation is completely voluntary. If you choose not to participate it will not impact our relationship or your relationship with Ryerson University.

The research has been reviewed and approved by the Ryerson REB (REB 2020-171).

If you are interested in more information about the study or would like to participate, please reply to me at mandeep.mann@,ryerson.ca.

Regards,

Mandeep Mann 


\section{Appendix B \\ In Person Recruitment Script}

Hello,

My name is Mandeep Mann. I am a student at Ryerson University in the Early Childhood Studies MA program. I wanted to talk to you about participating in my research study.

This research is being done as part of my Master's project and my supervisor's name is Dr. Susan Jagger. The focus of the research is to explore the experiences of children with 'ethnic' names who are experiencing their names being altered, changed, and/or mispronounced by themselves and/or others to assimilate them into the dominant culture. I will be exploring this through an autoethnographic study of my own experiences and related impacts. There will be a total of 7 non-active participants in this study.

If you agree to volunteer you will be asked to provide your ongoing consent to be a non-active participant in the study, meaning that you will not participate in data collection (i.e., you will not be interviewed, complete a survey, etc.). You will however participate through your inclusion in my reflective research writing (e.g., you will be included in my writing about experiences that you were present for). You will also be asked to provide demographic information on your ethnicity and your gender. You will be asked to reaffirm consent after initially reviewing research writing samples and after reviewing any major changes in how you are being featured in the research, and to reaffirm consent once a final draft is completed, and before the research project is disseminated.

Your participation is completely voluntary. If you choose not to participate it will not impact our relationship or your relationship with Ryerson University.

The research has been reviewed and approved by the Ryerson REB (REB 2020-171).

Do you have any questions for me at this time?

If you have any more questions about this process or if you need to contact me about participation, you may email me at mandeep.mann@,ryerson.ca. 


\section{Appendix C}

Consent Agreement

\section{Ryerson}

University

\section{Consent Agreement}

\section{South Asian Names, Identity, and Sense of Place}

You are being invited to participate in a research study. Please read this consent form so that you understand what your participation will involve. Before you consent to participate, please ask any questions to be sure you understand what your participation will involve.

Investigators:

This research study is being conducted by Mandeep Mann and supervised by Dr. Susan Jagger, from the School of Early Childhood Studies at Ryerson University. This study has been reviewed by the Ryerson University Research Ethics Board. [Protocol Number 2020-171]

If you have any questions or concerns about the research, please feel free to contact Mandeep Mann at mandeep.mann@,ryerson.ca.

Purpose of the Study:

The purpose of this autoethnographic study is to explore the experiences of children with 'ethnic' names who are experiencing their names being altered, changed, and/or mispronounced by themselves and/or others. Non-active participants will be included if they play a role in the researcher's racialized and/or name-based experiences. This research is being conducted in partial completion of the requirements for the degree of Master of Arts in the Program of Early Childhood Studies. The results will contribute to a major research paper.

What Participation Means:

There will be a total of 7 non-active participants in the study. If you volunteer to participate in this study, you will be asked to do the following:

1. Respond to the initial recruitment discussion or recruitment email sent out by the primary investigator.

2. Read this consent agreement and express any questions or concerns regarding the study to the primary investigator.

3. Sign and return this consent agreement before your data is included in the research.

4. You will be asked to provide demographic data regarding your ethnicity and gender.

5. Select how you would like to receive research writing samples that include you and representations of you within the study as well as a draft of the research before dissemination. 
6. If you wish to share any concerns about the final draft of the research, you will be asked to respond to the primary investigator within one week. If no response is received after the one week period, it will be assumed that you are satisfied with the text as is.

7. This research is expected to be completed by the end of August 2020 and will require your ongoing consent.

8. The research findings will be available to participants through e-mail as a final draft and online on Ryerson Library Digital Repository.

\section{Potential Benefits:}

This research aims to contribute to the South Asian community by giving representation to them within a place where western culture is dominant. This research also aims to inform people who alter or mispronounce 'ethnic' names and the effects that their actions have on South Asians with 'ethnic' names. Although this research focuses on the South Asian community, I believe that the findings can be significant for anyone whose names do not fit into the dominant culture and for those interacting with people whose names have been altered. You might reflect on your own identity, ethnic name, and impact of any alterations of that name. I cannot guarantee, however, that you will receive any benefits from participating in this study.

\section{Potential Risks:}

Potential risks to you in this study are low/minimal. You may feel uncomfortable with the written experiences that include you in the study. It is possible that you may have feelings of embarrassment related to the researcher's written representation of their lived experiences, a loss of privacy for information that you did not share with others, and possible damage to your reputation if the information shared regarding you is viewed as negative. The risk to personal identity being revealed for non-active participants is low/minimal. Information regarding your relationship to me, ethnicity, and gender will be collected for the study. It is possible that community members who know my family and friends can indirectly identify non-active participants by reading the research.

These risks to non-active participants will be minimized by ensuring that any identifying information that you did not consent to will not be shared within the study. You will be identified by a pseudonym in the research or by your relation to me (e.g., mother, father, partner, etc.). I will share with you research writing samples that include you for your review. You will be notified of any major changes to the representation of yourself within the study as well as a chance to review the final draft. You will also be reminded that you have the right to withdraw from the study at any point at all if you choose to do so.

\section{Confidentiality:}

In order to maintain confidentiality, all correspondence, data, and personal information will only be viewed by the Research Supervisor and I using the Ryerson Google Shared Drive accessed by password-protected Ryerson email as per Ryerson University guidelines. When not in use by the primary investigator, all physical copies of data will be kept in a locked cabinet in the home of the primary investigator. 
If you decide to stop participating in this study at any time, all information and data concerning you will be immediately deleted or destroyed. The final date after which participant data cannot be withdrawn is August $21^{\text {st }}, 2020$.

Confidentiality will be maintained by not sharing any identifying information that was not consented to. You will be identified by a pseudonym in the research or by your relation to me (e.g., mother, father, partner, etc.). In order to ensure that your information is kept confidential, you will have the opportunity to review research writing samples and any changes to your representation within the study as well as a final draft before dissemination. You will be given

the opportunity to voice your concerns regarding any changes that you feel need to be made in order to maintain your confidentiality.

Incentives to Participate:

The participant will not be paid to participate in this study.

Costs of Participation:

There are no anticipated costs associated with participation in this study.

Voluntary Nature of Participation:

Participation in this study is completely voluntary. By agreeing to participate in this research, you are not giving up or waiving any legal right in the event that you are harmed during the research. You can choose whether to be in this study or not. You may stop participating at any time. If you choose to stop participating, you may also choose to not have your data included in the study. Your choice of whether or not to participate will not influence your future relations with Ryerson University or the investigator (Mandeep Mann) involved in the research. The completion of this research is not dependant on your decision to participate or not participate in the study.

\section{Data Dissemination}

Data from this study will be used in a Major Research Paper to be submitted in partial completion of the requirements for the degree of Master of Arts in the Program of Early Childhood Studies. The research will be uploaded to the Ryerson Digital Library Repository by Fall 2020. It can be accessed online through https:/digital.library.ryerson.ca/.

Questions about the Study:

If you have any questions about the research now, please ask. If you have questions later about the research, you may contact:

Primary Investigator: Mandeep Mann at mandeep.mann@ryerson.ca

Research Supervisor: Dr. Susan Jagger at susan.jagger@ryerson.ca

This study has been reviewed by the Ryerson University Research Ethics Board [Protocol Number 2020-171]. If you have questions regarding your rights as a participant in this study, please contact: 
Research Ethics Board

c/o Office of the Vice President, Research and Innovation

Ryerson University

350 Victoria Street

Toronto, ON M5B 2K3

416-979-5042

rebchair@ryerson.ca

Confirmation of Agreement

Your signature below indicates that you have read the information in this agreement and have had a chance to ask any questions you have about the study. Your signature also indicates that you agree to participate in the study and have been told that you can change your mind and withdraw your consent to participate at any time. You have been given a copy of this agreement. You have been told that by signing this consent agreement you are not giving up any of your legal rights.

Name of Participant (please print)

Signature of Participant
Participant Email Address

Date 


\section{REFFERENCE LIST}

Adams, T. E., Jones S. H., \& Ellis, C. (2015) Autoethnography: Understanding qualitative research. New York: Oxford University Press

Anderson, L. (2006). Analytic autoethnography. Journal of Contemporary Ethnography, 35(4), 373-395. https://doi.org/10.1177/0891241605280449

Arefi, M. (1999). Non-place and placelessness as narratives of loss: Rethinking the notion of place. Journal of Urban Design, 4(2), 179-193. https://doi.org/10.1080/13574809908724445

Arefi, M. (2004). The pedagogy of the American city: Revisiting the concepts of place, nonplace, and placelessness. URBAN DESIGN International, 9(3), 103-117. https://doi.org/10.1057/palgrave.udi.9000121

Ashcroft, B., \& Ahluwalia, P. (2001). Edward Said (2nd Edition). Routledge. https://doi.org/10.4324/9780203137123

Assembly of First Nations. (2018, January 22). Dismantling the doctrine of discovery. Assembly of First Nations. Retrieved from https:/www.afn.ca/wp-content/uploads/2018/02/18-0122-Dismantling-the-Doctrine-of-Discovery-EN.pdf

Backhouse, C., \& Osgoode Society for Canadian Legal History. (1999). Colour-coded: A legal history of racism in canada, 1900-1950. Toronto, ON: University of Toronto Press.

Bains, S. K. (2020). Interrogating gender in Sikh tradition and practice. Religions (Basel, Switzerland), 11(1), 34. https://doi.org/10.3390/re111010034 
Bajaj, M., Ghaffar-Kucher, A., \& Desai, K. (2016). Brown bodies and xenophobic bullying in US schools: Critical analysis and strategies for action. Harvard Educational Review, 86(4), 481-505. https://doi.org/10.17763/1943-5045-86.4.481

Beneke, M. R., \& Cheatham, G. A. (2019). Race talk in preschool classrooms: Academic readiness and participation during shared-book reading. Journal of Early Childhood Literacy, 19(1), 107-133. https://oi.org/10.1177/1468798417712339

Berberich, C., Campbell, N., \& Hudson, R. (2012). Introduction: Framing and reframing land and identity. In C. Berberich, N. Campbell, \& R. Hudson (Eds.), Land \& identity: Theory, memory, and practice (pp. 17-40). New York, NY: Rodopi.

Berkel, C., Murry, V. M., Hurt, T. R., Chen, Y., Brody, G. H., Simons, R. L., Cutrona, C., Gibbons, F. X. (2009). It takes a village: Protecting rural African American youth in the context of racism. Journal of Youth and Adolescence, 38(2), 175-188. https://oi.org/10.1007/s10964-008-9346-z

Blumer, H. (2005). Society as symbolic interaction. In S. P. Hier (Ed.), Contemporary sociological thought: Themes and theories (pp. 91-100) Toronto, ON; Canadian Scholar's Press.

Broady, K. E., Todd, C. L., \& Darity, W. A. (2018). Passing and the costs and benefits of appropriating blackness. Review of Black Political Economy, 45(2), 104-122. https://doi.org/10.1177/0034644618789182

Burke, P. J., \& Stets, J. E. (2009). Identity theory. US: Oxford University Press. https://oi.org/10.1093/acprof:oso/9780195388275.001.0001 
Canada. (1901). Sessional papers of the Dominion of Canada. : 1901 Census v.A. Ottawa, ON: Harvard University. Retrieved from https://babel.hathitrust.org/cgi/pt? id=hvd.hwbz6s\&view $=1$ up \&seq $=7$

Canadian Institutes of Health Research. (2012). Canadian Bullying Statistics. https:/cihrirsc.gc.ca/e/45838.html

Carsignol, A. (2014). The construction, mobilization and limits of south Asianism in North America. South Asia Multidisciplinary Academic Journal, 10(10) https://oi.org/10.4000/samaj.3766

Carter, N., Bryant-Lukosius, D., DiCenso, A., Blythe, J., \& Neville, A. J. (2014). The Use of triangulation in qualitative research. Oncology Nursing Forum, 41(5), 545-547. https://doi.org/10.1188/14.onf.545-547

Cast, A. D., \& Burke, P. J. (2002). A theory of self-esteem. Social Forces, 80(3), 1041-1068. https://oi.org/10.1353/sof.2002.0003

Chen, J. M. (2017). The contentious field of whiteness studies. Journal for Social Thought, 2(1), $15-27$

Choi, A. Y., Israel, T., \& Maeda, H. (2017). Development and evaluation of the Internalized Racism in Asian Americans Scale (IRAAS). Journal of Counseling Psychology, 64(1), 52-64. https://doi.org/10.1037/cou0000183

Convery, I., Corsane, G., \& Davis, P. (2012). Making sense of place: Multidisciplinary perspectives. Woodbridge: Boydell Press. https:/doi.org/10.7722/j.ctt820r9 
Cresswell, T. (2008). Place: Encountering geography as philosophy. Geography, 93(3), 132-139. Retrieved from http://ezproxy.lib.ryerson.ca/login?url=https://search-proquestcom.ezproxy.lib.ryerson.ca/doc view/194757168?accountid=13631

Deep, K., \& Goyal, V. (2011). Development of a Punjabi to English transliteration system. International Journal of Computer Science and Communication, 2(2), 521-526.

Delgado, R. \& Stefancic, J. (2017). Critical race theory: An introduction (3rd ed.). New York University Press.

Deliovsky, K., \& Kitossa, T. (2013). Beyond black and white: When going beyond may take us out of bounds. Journal of Black Studies, 44(2), 158-181. https:/doi.org/10.1177/0021934712471533

Denzin, N. (2014). Reading and writing interpretation. In N. Denzin, Interpretive autoethnography (pp. 69-83). London: SAGE Publications. https://doi.org/10.4135/9781506374697

Dimitrova, R., Johnson, D. J., \& van de Vijver, F. J. (2018). Ethnic socialization, ethnic identity, life satisfaction and school achievement of Roma ethnic minority youth. Journal of Adolescence, 62, 175-183. doi: 10.1016/j.adolescence.2017.06.003

Ellis, C. (2007). Telling secrets, revealing lives: Relational ethics in research with intimate others. Qualitative Inquiry, 13(1), 3-29. https:/doi.org/10.1177/1077800406294947

Ellis, C., Adams, T. E., \& Bochner, A. P. (2011). Autoethnography: An overview. Forum: Qualitative Social Research, 12(1), 273-290.

Employment and Immigration Canada. (1993). Strategies for immigrant integration. Ottawa: Public Affairs, Author. 
Gatrad, R., Jhutti-Johal, J., Gill, P. S., \& Sheikh, A. (2005). Sikh birth customs. Archives of Disease in Childhood, 90(6), 560-563. https://doi.org/10.1136/adc.2004.064378

Ghosh, S. (2013). 'Am I a South Asian, really?' Constructing 'South Asians' in Canada and being South Asian in Toronto. South Asian Diaspora, 5(1), 35-55. https://doi.org/10.1080/19438192.2013.724913

Ginsberg, K. (1996). Passing and the fictions of identity. Durham, NC: Duke University Press.

Goodnight, M. R. (2017). Critical race theory in India: Theory translation and the analysis of social identities and discrimination in Indian schooling. Compare: A Journal of Comparative and International Education, 47(5), 665-683. https:/doi.org/10.1080/03057925.2016.1266926

Harpalani, V. (2013). Desicrit: Theorizing the racial ambiguity of South Asian Americans. New York University Annual Survey of American Law, 69(1), 77-184.

Harpalani, V. (2015). To be white, black, or brown? South Asian Americans and the race-color distinction. Washington University Global Studies Law Review, 14(4), 609-636.

Helms, J. E. (1993). An overview of Black racial identity theory. In J. E. Helms (Ed.), Black and White racial identity (pp. 9-32). Westport, CT: Praeger Publishers.

Hill, L. (2002). Black berry, sweet juice: On being black and white in canada (1st ed.) Toronto: Harper Perennial Canada.

Hogarth, K., \& Fletcher, W. L. (2018). A space for race: Decoding racism, multiculturalism and post-colonialism in the quest for belonging in Canada and beyond. Oxford, UK: Oxford University Press. 
Huber, L. P., Johnson, R. N., \& Kohli, R. (2006). Naming racism: A conceptual look at internalized racism in U.S. schools. Chicano Latino Law Review, 26, 183-206.

Hughes, D., Rodriguez, J., Smith, E. P., Johnson, D. J., Stevenson, H. C., \& Spicer, P. (2006). Parents' ethnic-racial socialization practices: A review of research and directions for future study. Developmental Psychology, 42(5), 747-770. https://doi.org/10.1037/00121649.42.5.747

Husband, T. (2010). He's too young to learn about that stuff: Antiracist pedagogy and early childhood social studies. Social Studies Research and Practice, 5(2), 61-75.

Husband, T. (2012). 'I don't see color”: Challenging assumptions about discussing race with young children. Early Childhood Education Journal, 39(6), 365-371. https://doi.org/10.1007/s10643-011-0458-9

Jagieła, J., \& Gębuś, D. (2015). What's in a name? Name giving, identity, and script formation. Transactional Analysis Journal, 45(3), 217-227. https://doi.org/10.1177/0362153715597721

Jakobsh, D. R. (2012). Sikhism. Honolulu: University of Hawai'i Press.

Kendall, L. (1998). Meaning and identity in "cyberspace": The performance of gender, class, and race online. Symbolic interaction, 21(2), 129-153.

Kennedy, R. (2001). Racial passing. Ohio State Law Journal, 62(3), 1145-1193.

Khalema, N. E., \& Wannas-Jones, J. (2003). Under the prism of suspicion: Minority voices in Canada post-September 11. Journal of Muslim Minority Affairs, 23(1), 25-39. https://doi.org/10.1080/13602000305928 
Kohli, R., \& Solórzano, D. G. (2012). Teachers, please learn our names! Racial microaggressions and the K-12 classroom. Race Ethnicity and Education, 15(4), 441-462. https://doi.org/10.1080/13613324.2012.674026

Kramer, M. W. \& Adams, T. E. (2017). Ethnography. In M. Allen (Ed.), The sage encyclopedia of communication research methods (Vol. 1, pp. 458-461). Thousand Oaks, CA: SAGE Publications. https $/ /$ doi.org/10.4135/9781483381411.n169

Lapadat, J. C. (2017). Ethics in autoethnography and collaborative autoethnography. Qualitative Inquiry, 23(8), 589-603. https://doi.org/10.1177/1077800417704462

Lee, D. L., \& Ahn, S. (2013). The relation of racial identity, ethnic identity, and racial socialization to discrimination-distress: A meta-analysis of black Americans. Journal of Counseling Psychology, 60(1), 1-14. https://doi.org/10.1037/a0031275

Li, P.S. (2003). Deconstructing Canada's discourse of immigrant integration. Journal of International Migration \& Integration 4(3), 315-333. https://doi.org/10.1007/s12134003-1024-0

Lockyer, S. (2012). Qualitative research, history of. In L. M. Given (Ed.), The sage encyclopedia of qualitative research methods (pp. 707-711). Thousand Oaks, CA: SAGE Publications. https://doi.org/10.4135/9781412963909

MacDonald, D. B. (2019). The sleeping giant awakens: Genocide, Indian residential schools, and the challenge of conciliation. Toronto, ON: University of Toronto Press. Retrieved from https://ebookcentral-proquestcom.ezproxy.1ib.ryerson.ca/lib/ryerson/detail.action?doc $\mathrm{ID}=5774584$

MacDonald, D. B., \& Hudson, G. (2012). The genocide question and Indian residential schools 
in Canada. Canadian Journal of Political Science, 45(2), 427-449.

https://doi.org/10.1017/S000842391200039

Maira, S. M. (2002). Desis in the house: Indian American youth culture in New York City. Philadelphia: Temple University Press.

Marcouyeux, A., \& Fleury-Bahi, G. (2011). Place-identity in a school setting: Effects of the place image. Environment and Behavior, 43(3), 344-362. https://oi.org/10.1177/0013916509352964

Marcus, L. (2018). Autobiography: A very short introduction. New York: Oxford University Press.

Maynard, R. (2017). Policing Black lives: State violence in Canada from slavery to the present. Halifax, NS: Fernwood Publishing.

Mohanty, J. (2013). Ethnic and racial socialization and self-esteem of Asian adoptees: The mediating role of multiple identities. Journal of Adolescence, 36(1), 161-170. https://doi.org/10.1016/j.adolescence.2012.10.003

Mucina, M. K. (2019). Spirituality and a search for home: The complexities of practising Sikhism on Indigenous land. In N. N. Wane, M. S. Todorova, K. L Todd. (Ed.), Decolonizing the spirit in education and beyond (pp. 23-43). Cham, Switzerland: Palgrave Macmillan.

Museus, S. D. \& Iftikar, J. (2013). Critical racial contexts. In S. D. Museus (Ed.) Asian American students in higher education (pp. 9-29). New York: Routeledge 
Nadal, K. L., Griffin, K. E., Wong, Y., Hamit, S., \& Rasmus, M. (2014). The impact of racial microaggressions on mental health: Counseling implications for clients of color. Journal of Counseling and Development, 92(1), 57-66. https://doi.org/10.1002/j.1556$\underline{6676.2014 .00130 . x}$

Nic Craith, M. (2012). Narratives of place, belonging and language: An intercultural perspective. London, UK: Palgrave Macmillan. Retrieved from https://ebookcentralproquest-com.ezproxy.lib.ryerson. ca/lib/ryerson/detail.action?docID=851056.

Nolan, A., Macfarlane, K. \& Cartmel, J. (2013). Research in Early Childhood. London: Sage.

Ontario Ministry of Education. (2014). How does learning happen? Ontario's pedagogy for the early years. Toronto: Author.

Palsson, G. (2014). Personal names: Embodiment, differentiation, exclusion, and belonging. Science, Technology, \& Human Values, 39(4), 618-630. https://doi.org/10.1177/0162243913516808

Patterson, O. (1982). Slavery and social death: A comparative study. Cambridge, MA: Harvard University Press.

Pauker, K., Apfelbaum, E. P., \& Spitzer, B. (2015). When societal norms and social identity collide: The race talk dilemma for racial minority children. Social Psychological and Personality Science, 6(8), 887-895. https://doi.org/10.1177/1948550615598379

Pennesi, K. (2016). "They can learn to say my name": Redistributing responsibility for integrating immigrants to Canada. Anthropologica 58(1), 46-59. https://doi.org/10.3138/anth.581.A03 
Peterson, B., Gunn, A., Brice, A., \& Alley, K. (2015). Exploring names and identity through multicultural literature in K-8 classrooms. Multicultural Perspectives, 17(1), 39-45. https://oi.org/10.1080/15210960.2015.994434

Priest, N., King, T., Bécares, L., \& Kavanagh, A. M. (2016). Bullying victimization and racial discrimination among Australian children. American Journal of Public Health, 106(10), 1882-1884. https://doi.org/10.2105/AJPH.2016.303328

Public Health Agency of Canada. (2016). How to recognize bullying. Government of Canada. https://www.canada.ca/en/public-health/services/bullying/how-recognize-bullying.html

Queirós, A., Faria, D., \& Almeida, F. (2017). Strengths and limitations of qualitative and quantitative research methods. European Journal of Education Studies, 3(9), 369-387. https://doi.org/10.5281/zenodo.887089

Radhakrishnan, R. \& Koshy, S. (2008) Transnational South Asians: The Making of a NeoDiaspora. Delhi: Oxford University Press.

Ramsaran, D., \& Lewis, L. (2018). Caribbean masala: Indian identity in Guyana and Trinidad. Jackson, MS: University Press of Mississippi.

Ray, V. E., Randolph, A., Underhill, M., \& Luke, D. (2017). Critical race theory, Afropessimism, and racial progress narratives. Sociology of Race and Ethnicity, 3(2), 147158.

Richardson, L., \& St. Pierre, E. A., (2005). Writing: A method of inquiry. In N. K. Denzin \& Y. S. Lincoln (Eds.), The SAGE handbook of qualitative research (3rd ed., pp. 959-978). Thousand Oaks, CA: SAGE Publications 
Rose-Redwood, R. (2016). "Reclaim, rename, reoccupy": Decolonizing place and the reclaiming of PKOLS. ACME: An International E-Journal for Critical Geographies, 15(1), 187206. https:/acme-journal.org/index.php/acme/article/view/1215

Said, E. W. (1978). Orientalism (1st ed.) New York: Vintage Books.

Sanagavarapu, P. (2010). What does cultural globalisation mean for parenting in immigrant families of the 21st century? Australasian Journal of Early Childhood, 35(2), 36-42. https://oi.org/10.1177/183693911003500206

Smith, A. (2006). Heteropatriarchy and the three pillars of white supremacy: Rethinking women of color organizing. In Incite! Women of Color against Violence (Ed.), Color of violence: The incite! anthology (pp. 66-73). Cambridge, Mass: South End Press.

Smythe, S., \& Toohey, K. (2009). Investigating sociohistorical contexts and practices through a community scan: A Canadian Punjabi-Sikh example. Language and Education, 23(1), 37-57. https://doi.org/10.1080/09500780802152887

Souto-Manning, M. (2007). Immigrant families and children (re)develop identities in a new context. Early Childhood Education Journal, 34(6), 399-405. https://oi.org/10.1007/s10643-006-0146-3

Spry, T. (2001). Performing autoethnography: An embodied methodological praxis. Qualitative Inquiry, 7(6), 706-732. https://doi.org/10.1177/107780040100700605

Srinivasan, R. (2019). Experiences of name-based microaggressions within the South Asian American population (Doctoral dissertation, Columbia University, New York, United 
States). Retrieved from http://ezproxy.lib.ryerson.ca/login?url=https://search-proquestcom.ezproxy.lib.ryerson.ca/doc view/2287470626?accountid=13631

Staszak, J. (2009). Other/otherness. In R. Kitchin \& N. Thrift (Ed.), International encyclopedia of human geography: A 12-volume set (1st ed., pp. 1-7). Oxford: Elsevier Science. Retrieved from https://archive-ouverte. unige.ch/unige:77582

Statistics Canada. (2017a). Census Profile, 2016 Census: Ontario [Province] and Canada [Country] [Table] Retrieved from https://www12.statcan.gc.ca/censusrecensement/2016/dp-pd/prof/index.cfm?Lang $=\mathrm{E}$

Statistics Canada. (2017b). Census Profile, 2016 Census: Canada [Country] and Canada [Country] [Table]. Retrieved from https://www12.statcan.gc.ca/censusrecensement/2016/dp-pd/prof/index.cfm?Lang=E

Stets, J. E., \& Burke, P. J. (2000). Identity theory and social identity theory. Social Psychology Quarterly, 63(3), 224-237. https://doi.org/10.2307/2695870

Stets, J. E., \& Burke, P. J. (2014). Self-esteem and identities. Sociological Perspectives, 57(4), 409-433. https://doi.org/10.1177/0731121414536141

Stryker, S., \& Burke, P. J. (2000). The past, present, and future of an identity theory. Social Psychology Quarterly, 63(4), 284-297. doi:10.2307/2695840

Sue, D. W., Bucceri, J., Lin, A. I., Nadal, K. L., \& Torino, G. C. (2009). Racial microaggressions and the Asian American experience. Asian American Journal of Psychology, S(1), 88101. https://doi.org/10.1037/1948-1985.S.1.88 
Sue, D. W., Capodilupo, C. M., Torino, G. C., Bucceri, J. M., Holder, A. M. B., Nadal, K. L., \& Esquilin, M. (2007). Racial microaggressions in everyday life: Implications for clinical practice. American Psychologist, 62(4), 271-286. https://oi.org/10.1037/0003066X.62.4.271

Sue, C., \& Telles, E. (2007). Assimilation and gender in naming. The American Journal of Sociology, 112(5), 1383-1415. https://doi.org/10.1086/511801

Taylor, S. (2015). 'Home is never fully achieved ... even when we are in it': Migration, belonging and social exclusion within Punjabi transnational mobility. Mobilities, 10(2), 193-210. https://doi.org/10.1080/17450101.2013.848606

Team ReconciliAction YEG. (2018). What's in a name? Renaming and reclaiming of indigenous space. Edmonton, AB: University of Alberta Faculty of Law Blog. https://ualbertalaw.typepad.com/faculty/2018/11/whats-in-a-name-renaming-andreclaiming-of-indigenous-space-.html

Tewksbury, R. (2009). Qualitative versus quantitative methods: Understanding why qualitative methods are superior for criminology and criminal justice. Journal of Theoretical and Philosophical Criminology, 1(1), 38-58.

Tuck, E., \& Yang, K. W. (2012). Decolonization is not a metaphor. Decolonization: Indigeneity, Education \& Society, 1(1), 1-40.

United States Department of Labor Office of Policy Planning and Research. (1965). Negro family: The case for national action. Washington, DC: United States Government Printing Office. 
Vidich, A. J., \& Lyman, S. M. (1994). Qualitative methods: Their history in sociology and anthropology. In G. Crozier, N. K. Denzin, \& Y. S. Lincoln (Eds.), Handbook of qualitative research (1st ed., pp. 23-44). Thousand Oaks, CA: SAGE Publications.

Vine, T., Clark, J., Richards, S., \& Weir, D. (2017). Introduction. In Vine, T., Clark, J., Richards, S., \& Weir, D. (Eds.), Ethnographic research and analysis: Anxiety, identity and self (pp. 1-12). London: Palgrave Macmillan. https://doi.org/10.1057/978-1-137-58555-4

Wang, J., Leu, J., \& Shoda, Y. (2011). When the seemingly innocuous "stings": Racial microaggressions and their emotional consequences. Personality and Social Psychology Bulletin, 37(12), 1666-1678. https://doi.org/10.1177/0146167211416130

Ward, W. P. (2002). White Canada forever: Popular attitudes and public policy toward orientals in British Columbia (3rd ed.) McGill-Queen's University Press.

Yee, J. (2005). Critical anti-racism praxis: The concept of whiteness implicated. In J. Fook, S. Hick, \& R. Pozzuto (Eds.), Social work: A critical turn (pp. 87-104). Toronto, ON: Thompson Educational Publishing.

Young, B. (2015). "Killing the Indian in the child": Death, cruelty, and subject-formation in the Canadian Indian residential school system. Mosaic: A Journal for the Interdisciplinary Study of Literature, 48(4), 63-76. https://doi.org/10.1353/mos.2015.0054 